\title{
The Effects of Venture Capitalists on the Governance of Firms
}

\author{
Stefano Bonini* \\ Bocconi University \\ Department of Finance \\ Via Roentgen 1, 20136, Milan, Italy \\ stefano.bonini@unibocconi.it \\ Senem Alkan \\ Bocconi University \\ Department of Finance \\ Via Roentgen 1, 20136, Milan, Italy \\ saktuccar@cd.zodiac.com \\ Antonio Salvi \\ LUM “Jean Monnet” University, Bari, Italy \\ and \\ SDA Bocconi Business School, Via Bocconi 8, 20136, Milan, Italy \\ antonio.salvi@sdabocconi.it
}

This draft: July 2011

JEL classification Codes: G24, G32, G34

Keywords: Venture Capital, Corporate Governance

The authors acknowledge financial support from Università Bocconi. This paper has been completed while Stefano Bonini was Visiting Associate Professor at NYU- Stern School of Business. We thank the Editor, William Judge, the Associate Editor Eduardo Schiehll and three anonymous referees for invaluable guidance. We are grateful to Stefano Caselli, Pedro Santa-Clara, Stefano Gatti, Douglas Cumming, Marina Balboa, Juan-Carlos Gomez Sala and seminar participants at the Bocconi University Seminar 2006, UCLA Finance Seminar 2006, EFMA Meeting 2007, NYU seminar 2009 for helpful comments. We are specially indebted with Simona Zambelli and Davide Ravasi for providing insightful suggestions. The ideas expressed in the paper do not necessarily reflect those of the authors' affiliation. Any errors remain our own.

* corresponding author: E-mail: stefano.bonini@unibocconi.it, Ph. +39 0258363612 


\title{
The Effects of Venture Capitalists on the Governance of Firms
}

\begin{abstract}
Manuscript Type: Empirical

Research Question/Issue: What determines venture capitalists influence on the governance of firms? How do venture capitalists shape the governance of their investees? Are venture capitalists governance practices consistent across countries? These important questions are under-investigated in the extant literature. In this study, we shed light on the effects of venture capital investors on a large set of governance decisions and we discover the existence of striking cross-country differences.

Research Findings/Insights:

We test our conjectures on a unique hand-collected questionnaire-based dataset of 164 companies in 5 countries and 2 regions (Europe and the US). Our empirical results show that there is a strong and positive relationship between VCs' funding and their influence on some factors like decisions on CEO hiring, executive compensation, board decisions and appointments. Employee incentives are also positively related to the proportion of $\mathrm{VC}$ funding. On the other hand, results show that the proportion of VC funding is only limitedly significant in explaining VC influence on strategy direction and investment planning. Our analysis though, offers a remarkably different view after splitting data into European and American subsamples.

\section{Theoretical/Academic Implications:}

Our results provide a novel view of the functioning of the Venture Capital industry and its degree of pervasiveness in the management of portfolio companies. Adopting a unique dataset we add new evidence on detailed governance decisions, thus supporting the idea that the incremental contribution of a professional investor to a new venture is largely exceeding the capital infusion only. Finally, we show that governance decisions exhibit significant country effects. This evidence supports the view that a global theory of corporate governance cannot rely on a single interpretation framework such as agency theory, but needs to be integrated with predictions from alternative views such institutional theory.

Practitioner/Policy Implications: Corporate governance is the essential mechanism allowing proper management of financial and corporate resources by aligning incentives of employees and investors, thus enabling oversight and control on companies. Yet, corporate governance rules and mechanisms are costly and have different effectiveness across countries. Our results provide guidance to investors in selecting the appropriate set of governance provisions conditional on a set of investment-specific factors.
\end{abstract}




\section{INTRODUCTION}

Recent growth in the Venture Capital (VC) industry has stimulated new academic research exploring the structure of Venture Capital deals. Gompers (1995), Hellman and Puri (2002), Kaplan and Stromberg $(2003,2004)$ show that VCs not only support firms with essential financing, but also provide value-added services to their portfolio companies $^{\mathrm{i}}$ aimed at monitoring the progress and the strategy of firms. While we know much more than earlier studies, several research questions are still waiting answers, including the role and effects of VCs on the inner governance of firms, conditional and unconditional on the size of the investment injected and on the geographical area of the portfolio company.

In this paper we contribute to this recent stream of research providing evidence on the effects of VC funding on the corporate governance mechanisms in VC-backed firms. In this effort we differentiate from previous studies in several ways. First, we construct an original questionnaire-based dataset by surveying 164 VC-backed companies in six countries, to analyze the previously unexplored relationship between VC funding and the governance of portfolio companies. In particular, we introduce a more informative explanatory variable such as the proportion of $\mathrm{VC}$ funding instead of a simple dummy characterization as, for instance, in Hellmann and Puri (2000; 2002). The rationale for this choice is based on the theoretical and empirical contributions of Kanniainen and Keuschnigg, (2003, 2004); Bernile et al., (2007), Cumming (2006) that show that VC investors carefully select the size of the economic interest they acquire in a company in order to efficiently use their limited monitoring and advisory skills. Secondly, the surveybased nature of our study allows us to investigate the effect of VCs on a broader range of governance variable, unavailable through standard data sources, namely: CEO hiring, human resource practices, executive compensation, employee incentives, board decisions, board appointments, strategy direction and investment planning. Finally, we provide previously unavailable evidence on the regional differences in VCs influence on portfolio companies corporate governance decisions. In the light of the ongoing debate on the development of a global corporate governance theory, the limited focus of the extant literature on either single country analyses or coarse governance metrics, is likely failing to properly capture a significant fraction of information. Our contribution, fills this gap 
providing new evidence on the existence of persistent regional differences. In this paper we do not provide an explicit test on the causes of these differences. Yet, we argue that differential cross-country results may be related with three different factors: first the existence of different regulation and standards in the two areas as recently highlighted by Cumming (2008); second by different levels of institutionalization of VCs in the two areas: VC market in the US has developed much earlier than in Europe due to several factors, among which the existence of an effective regulation on closed-end funds is of paramount importance; on the other hand, most European countries have developed similar rules only in the late '90s (EVCA 2006). Third, development capital in Europe has traditionally been offered to companies by banks and, in some cases, large corporations. These institutions have traditionally been comparatively less involved in the governance of investees than independent US venture capital firms, given the different characteristics and lower risk of bank and corporate financing.

In our full sample regressions, we find a strong positive relationship between VCs' funding and their influence on CEO hiring, executive compensation, employees incentives, board decisions and board members appointments. On the other hand, results show that the proportion of $\mathrm{VC}$ funding is only limitedly significant in explaining $\mathrm{VC}$ influence on strategy direction and investment planning. Differently from results in Hellmann and Puri (2002) on the effects of VCs on human resources (HR) policies, our evidence suggests a weaker relationship between the amount of $\mathrm{VC}$ funding and $\mathrm{VC}$ influence on HR practices.

Splitting data into European and American VC-backed companies, we aimed at assessing similarities and differences in the two regions which may be motivated by legal, structural and cultural issues. Surprisingly, the two regions show strikingly different regularities with regards to corporate governance decisions: the proportion of $\mathrm{VC}$ funding is strongly significant in explaining the $\mathrm{VC}$ influence on executive compensation, board decisions, and board appointments in US VC-backed companies while in European VC-backed companies, the amount of VC funding is positive and significantly related only to $\mathrm{VC}$ influence on investment planning. CEO hiring is similarly influenced by VCs both in Europe and US but considerably different HR practices are observed cross-country. 


\section{THEORETICAL BACKGROUND AND HYPOTHESES}

Theoretical literature argues that when ownership and control are separated, principals develop governance structures to reduce agency costs and align agents' incentives (Jensen and Meckling (1976), Grossman and Hart (1986), Zingales (1995)). Likewise, optimal financial structure design by financial intermediaries can effectively help mitigating agency problems by identifying self-enforcing equilibria (Diamond (1984), Fama (1985), Stiglitz (1985), Bhattacharya and Thakor (1993), Barry (1994)). A particularly fruitful testing ground for agency theories is the VC industry: since venture capital deals are primarily characterized by asymmetric information between entrepreneurs and financiers and almost exclusive capital infusion by outsiders, it is extremely likely to observe agency problems. In this spirit, Gorman and Sahlman (1989) and Sahlman (1990) first suggested that the value of VC lies not only in providing capital but also in superior selectivity by consistently picking high-growth firms, and in the provision of supplementary services such as: entrepreneurial advice, executives hiring and strategy shaping, resulting in a valuable "professionalization" of portfolio companies. Following these seminal contributions, a large number of studies have investigated the mechanisms adopted by VCs to mitigate principal-agent conflicts identifying three broad classes of control mechanisms: intense pre-investment screening, the development of accurate financing contracts, and continuous post-investment monitoring and advisory. Admati and Pfleiderer (1994), Lerner (1994a), Hochberg, Ljungqvist, and Lu (2007) shed light on pre-investment screening and syndication. Sahlman (1990), Berglof (1994), Gompers (1995), Bergmann and Hege (1998) provide extensive evidence on the increasing level of complexity in the design of $\mathrm{VC}$ financing contracts through the introduction of staging, monitoring, government and exit rules. This evidence is supported by Cumming (2005) who shows that agency problems are explicitly addressed by appropriate security design and that the degree of contractual sophistication changes over time due to learning effects. Finally, recent research has given increasing attention to the valuable activities performed by $\mathrm{VC}$ beyond their financing function. Particularly, value-added tasks of $\mathrm{VC}$ include helping firms to shape strategies, providing technical 
and commercial advice (Bygrave and Timmons (1992), Hellmann (1998), Hellmann and Puri (2002), Baker and Gompers (2003) Cornelli and Yosha (2003))

Several questions though, remain unanswered in particular with regards to the extent of the influence of VCs on the governance of firms. Fama and Jensen (1983) and Williamson (1983), first conjectured that the composition of the board should be shaped by the need for oversight. Lerner (1995) tests this intuition in the VC industry by looking at board representation of portfolio companies. Assuming that VCs are significant providers of managerial oversight, their representation on boards should be larger when there is a greater need for oversight. His findings show that VCs are more likely to join or be added to the boards of private companies in periods when the CEO of the company changes. Baker and Gompers (1999) focus on board composition at IPOs. They argue that the optimal choice for board structure is made at the time of the IPO since existing shareholders bear the cost of suboptimal governance. Using data from 1,116 IPO prospectuses, they describe board size and composition for a set of firms with a median age of less than six years and a median equity capitalization of $\$ 42$ million. According to their analysis, the number of insiders is 27 percent smaller in VC-backed firms, and the number of instrumental directors is 20 percent smaller. Kroszner and Strahan (2001) using banks board representation obtain similar results. Hellmann and Puri (2002), provide additional insights on a set of governance actions in a hand-collected survey sample of 149 startups in the Silicon Valley. The authors show that VCs are influential not only at the top of the organization, in terms of replacing the original founders with an outside CEO as in Lerner (1995), but also in the developments further down the organization. Differently from previous studies, Kaplan and Stromberg (2000, 2004) document direct evidence on VC actions and monitoring. Analyzing investment decisions on portfolio companies at the time of the initial investment they find that while in $14 \%$ of the investments the VCs play an active role in advising the management, they trade off this activity with the costs of devoting excessive attention to a single venture. Hochberg (2004) compares governance in VC and non VC-backed IPO firms using a unique database assembled by supplementing data from four publicly available databases with additional information gathered from two hand-collected datasets. Results show that VC backing reduces the level of earnings management in the firm (as proxied for by 
discretionary accruals); furthermore VC-backed firms are more likely to follow "conservative" rather than "aggressive" "ii accounting practices than non VC-backed firms. Additionally, VC-backed firms experience higher abnormal returns upon the announcement of the adoption of a shareholder rights agreement than non VC-backed firms and have more independent board structures at the time of the IPO. In a similar setup, Suchard (2009) explores the effect of VC backing on the size and composition of the board of directors of investees at the time of IPO, showing that VC are influential in determining the number of board members and in appointing independent directors with substantial industry-related skills. Cumming et al. (2008) address the issue of the governance of $\mathrm{VC}$ companies conditional on the legal and economic framework. Their results, although focused on a broad set of corporate variables relating to governance style by VC investors, offer a first hint at the existence of profound differences in the governance choices by $\mathrm{VC}$ investors conditional on their geographical origins.

\section{Hypotheses}

These contributions confirm the intuition that VCs do affect the governance of their portfolio companies by intense monitoring, providing advice, shaping strategies and accelerating companies growth. Surprisingly, though, existing studies leave two important issues largely unexplored: firstly, the link between the amount of $\mathrm{VC}$ financing and $\mathrm{VC}$ effect on company governance and secondly, the degree of convergence across regions of venture capitalists effects on portfolio companies' governance structures.

The relevance of size in the selection and management process of VC deals has been addressed in a set of recent theoretical and empirical contributions (Kanniainen and Keuschnigg, 2003, 2004; Bernile et al., 2007, Cumming 2006). In particular Kanniainen and Keuschnigg, $(2003,2004)$ and Bernile et al. (2007) show that since the size of a VC management company cannot be easily scaled to the number of ventures in the portfolio, the screening, monitoring and advice activity of that management company is upper bounded. As a consequence, VC investors will optimize their available time and effort by carefully selecting the size of the portfolio (number of investments), to achieve optimal passive diversification, and the stake in each venture in order to optimally allocate their monitoring (scarce) resources. The latter decision can be also interpreted as a 
diversification effect as VC will devote more resources to project where they have larger interests and accept more risks on project where they have smaller stakes (Jääskeläinen et al., 2006). Bernile et al. (2007) test this empirical predictions on a survey-based sample of 42 VC-backed companies. Their results confirm the theoretical model showing that $\mathrm{VC}$ investors jointly optimize the size of the portfolio and the relative weights of each investment. Cumming (2006) addresses the portfolio size issue showing that additional factors such as industry, stage, syndication and geographical region contribute to the portfolio size selection.

These results suggest that when the economic interest of a $\mathrm{VC}$ in a company increases, the monitoring and advice effort should increase accordingly and, consequently, the effect of $\mathrm{VC}$ investors on the governance of portfolio companies should be stronger and more pervasive. Accordingly we formulate the following hypothesis that we expect to hold with positive sign on the selected governance variables.

HP 1: as the amount of VC funding in a company grows, VC influence on the governance of such a company increase.

VC investments are characterized by high risk due to the uncertainty associated with the venture idea - that often involves substantial, untested technological innovation-, the early stage of the venture, its relative illiquidity and to the intrinsic information asymmetry between the founder and the investors (Sahlman, 1990). As such, VC investments are subject to non-negligible agency risks (Manigart and Sapienza, 2000). Agency problems mitigation is therefore one of the main concerns of $\mathrm{VC}$ investors who will seek greater control over their portfolio companies than traditional investors. Van de Berghe and Levrau (2002) show that monitoring by VCs can be exerted through elaborated shareholders agreements that, however, are largely incomplete. As Kaplan and Stromberg (2003) showed, complete contingent contracts are impossible to design, in particular in such a set-up, forcing VCs to exert monitoring through alternative channels. Aoki (1999) argues that this objective is pursued by "exercising a broad range of governance roles". These can take place in a multitude of different ways from requiring seats in the Board of Directors to negotiating strategy and business development 
decisions with the CEO. However, the payoffs from implementing different firm-level governance mechanisms differ across countries, as highlighted by Doidge, Karolyi, and Stulz (2007), and John and Kedia (2006). Aggarwal et al. (2009, p. 3132) argue that "the internal governance of firms in the United States [...] provides a benchmark" to evaluate other mechanisms as it "come as close as possible to what the optimal internal governance of a firm would be in a foreign country if it were not constrained by weaker institutions and lower development than in the United States". The authors show that these differences have a large effect on the value of companies in that the value of foreign firms decreases as their governance quality decreases below that of matching US-firms. This result is noteworthy as $88 \%$ of the foreign companies have lower governance quality than their US counterparties. Goergen et al. (2005) and Chhaochharia and Leaven (2011) support this view showing that in large cross-country analyses European systems systematically rank below Anglo-American ones and that within the latter group, the US system prevails. ${ }^{\text {iii }}$ In our analysis we classify as European also UK companies. This approach may be subject to criticism as several authors have pointed out that the UK and the US systems show several similarities in terms of economic environment (La Porta et al., 2008). However, the Aggarwal et al. (2009) study show that less than $25 \%$ of the UK companies in the sample have better governance than that of matching US firms, against a European average of $12 \%$. The authors notice on one hand that the larger figure is possibly due to the similarity of the legal system to that of the US but on the other, that additional factors prevail in likening the UK more to other European countries. Hopt and Leyens, (2004), Denicolo, Laeven and Ueda, (2008), Goergen et al. (2009) and Chhaochharia and Leaven (2011), highlight that the actual selection of governance mechanisms varies considerably across regions, supporting the the arguments in Yoshikawa and Rasheed (2009). Khanna, Kogan and Palepu (2006) conjecture that even if governance mechanisms may formally become closer (de jure convergence) actual practices may still be distant apart (de facto convergence). These institutional differences may directly result in a different choice of the corporate governance mechanisms by VC investors. Schwienbacher (2008) show that European VC investors, are remarkably less involved in the management and monitoring of their portfolio companies than their US counterparts. Similarly, Cumming et al. (2010), show evidence that VC practices are 
affected by regional biases such as managerial culture, the level of institutionalization of VC development and property rights enforcement practices. These results are aligned with the view in Judge et al. (2010) that agency theory provides more reliable predictions in environments where neoclassical assumptions are limitedly violated, such as the US. Differently, when the economic environment is more deeply influenced by institutional structures, such as in Europe, agency theory may fail to describe the true behavior of firms. Following these arguments, we conjecture:

$H P$ 2: US VC-backed companies will experience higher VC influence on corporate governance mechanisms than European VC-backed peers.

VC investments are often syndicated, i.e. capital is provided by a pool of investors rather than a single venture capitalist. The rationale for this feature is that by syndicating, investors can exert optimal portfolio diversification, superior selectivity and more efficient monitoring (Gompers and Lerner, 2006). Syndication then reduces ex-ante uncertainty by allowing superior investment screening (Casamatta and Haritchabalet, 2007) that results in a lower default ratio and higher overall performance of syndicated investments as opposed to single-VC investments (Tian, 2008). However, syndication generates also adverse selection and free-riding problems (Kotha, 2008; Jääskeläinen et al., 2006) that may translate in higher, rather than lower default rates (Dimov and DeClerq, 2006) due to lower ex-post monitoring and control. This latter relationship is defined by agency theorists a "principal-principal" agency problem (Young et al., 2002) In this context the primary issue is the opportunistic behavior between investors (Shleifer and Vishny, 1997). A natural control mechanism is an appropriately designed investment agreement between the syndicate members. However since contracts are largely incomplete in VC deals also at the investors level (Kaplan and Stromberg, 2003), the effectiveness of contracts in mitigating principal-principal problems can be weak. A viable solution to reduce these agency costs is implementing elaborated governance structures that should allow a timely recognition of distress signals by all syndicate members and an effective exit choice by investors (Jääskeläinen, 2009). ${ }^{\text {iv }}$ For instance, non-lead syndicate members may require the presence of more independent directors than 
would be the case in a single VC-backed venture to limit the lead-syndicate discretion. Similarly, they may require greater oversight on strategic decisions that may prove beneficial to some syndicate members and not to others due, for example to portfolio synergies. In such a setup, therefore, we should observe a more widespread influence of $\mathrm{VC}$ investors in the shaping of governance practices. These arguments lead us to the following hypothesis:

HP 3: As the number of different investors for a VC-backed firm increases, we expect a greater amount of VC influence and control on the governance of firms.

\section{DATA AND SUMMARY STATISTICS}

\section{Data description}

A common problem in cross-country investigations on the governance of firms is the limited availability of reliable and consistent data due to the internal, non public nature of this information. This problem is particularly relevant for young, private companies such as those most likely to receive VC financing, as also highlighted by Cumming et al. (2008). The vast majority of existing papers rely on well-known data suppliers such as Venture Economics and Venture One ${ }^{\mathrm{v}}$. Unfortunately, these data providers tend to include only standard accounting, financial and organization items such as capital infusions, investors involved in the deals, staging of capital contributions, performance metrics, board membership and exit strategies (Kaplan et al., 2002).

In this paper, we have gathered information on a set of detailed governance practices by developing a novel hand-collected, questionnaire-based survey database. The data collection process has been as follows: first, we selected 20 European countries surveyed by EVCA plus the United States, for which we had consistent and reliable data on both VC firms and companies. Second, we calculated the mean value of the sum of VC investments (in USD Mil) for the 2000-2005 period, divided by each country's GDP level for the same window ${ }^{\mathrm{vi}}$. We then removed all countries below the mean $\mathrm{VC}$ investments value, ending up with six countries: US, UK, France, Spain, Germany and Sweden. Third, from Venturexpert database, we randomly extracted $500 \mathrm{VC}$ backed companies incorporated in the selected countries, which received first venture financing 
between year 2000 and 2005. Additional data on selected companies has been gathered from EVCA, and NVCA annual reports. Discontinued, acquired, or floated companies are excluded and random extraction is run again to refill the available slots. Thus, in the final list of 500 randomly selected companies, we only have companies that (1) have been first VC-backed between 2000 and 2005, (2) are still operating, (3) have not been acquired or publicly traded. The rationale for selecting a five-year period is to allow sufficient time for observing the $\mathrm{VC}$ influences without introducing too old firms in the sample.

We have executed our survey between the end of 2006 and the first half of 2007 by submitting questionnaires by email (80\%) and by fax $(20 \%)$ to target companies' executives, namely CEOs, CFOs or COOs. The response rate has been $32.8 \%$ with 164 respondents. ${ }^{\text {vii }}$ The company role distribution of respondents has been as follows: $52 \%$ of the respondents have declared to act as CEOs, Chairman or as holding both positions with pure CEOs representing over $86 \%$ of the respondents in this category; $32 \%$ of the surveyed individuals identified their role as CFOs; $8 \%$ of questionnaire submitters identified themselves as COOs, $4 \%$ as R\&D VPs and the remaining $4 \%$ indicating a miscellanea of top-management roles such as founder or Business development director. Although questionnaires have been followed up to control for the respondents true identity, we cannot rule out the possibility that some questionnaires have been filled by a different person or by an assistant. This is a common problem in survey-based research also encountered by Cumming (2009), Helmman and Puri (2000, 2002) in similarly structured survey-based studies on Venture Capital activity and governance and, analogously, we reckon this as a possible weakness. The questionnaire is reproduced in Table A1 in the Appendix and is partitioned into three sections. The first section addresses company information such as the year of company inception, the industry, the number of employees, the geographic location, the geographic location of its venture capitalists, the number of VC investors between 2000 and 2005, and the amount of VC financing received in absolute and percentage terms by each investor. This section is used to cross-check archival demographic information provided by the European Venture Capital Association (EVCA), National Venture Capital Association (NVCA), VentureXpert, and portfolio companies' websites. The second section is the core of the 
questionnaire and addresses specific issues on the impact of VCs on the governance of firms. Finally, the third section includes information about the respondents' position within the company and their suggestions about other potential influences of VCs in the company governance..

Variables are operationalized as Likert-type items with values ranging from 1 to 4, where 1 indicates ' $n o$ ' VC influence and 4 'high' VC influence. In choosing the scaling we opt for a four point scale rather than a 5 or 7 scale to avoid neutral responses that could possibly appear in the latter scaling. As shown by Garland (1991) this choice yields more informative results when the respondents are likely to submit socially acceptable responses. ${ }^{\text {viii }}$

In defining the design of the questionnaire governance items, we reviewed and followed prior contributions in the VC literature and highlight three main areas of activity: CEO replacement, Strategy Direction and Human Resource Practices.

Entrepreneurial companies are crucially related to the human capital of the founder who generally acts as a $\mathrm{CEO}$ at the time of the $\mathrm{VC}$ funding. However, as theoretically and empirically shown by Lerner (1995), Hellmann (1998), Bruton et al. (1997, 2000) among others, entrepreneurs are not necessarily effective company managers. As such, VC investors often require or impose the CEO replacement on or soon after the capital contribution. Baker and Gompers (2003) confirm this conjecture showing that VCs are crucial factors in the timing and choice of the switch between an outside CEO and the founder-CEO. We address these issues by modeling one dichotomous variable, CEO-replaced, capturing whether the $\mathrm{CEO}$ has been replaced after the VC capital injection. We expect a positive relationship of this dependent variable with $\mathrm{VC}$ investment size.

Hellmann and Puri (2000), and Kaplan and Stromberg (2000) highlight that VCs take part in developing and/or improving strategies, strategic alliances, and investment planning through mergers and acquisitions. Hochberg (2004) and Suchard (2009) have shown that VCs are influential in shaping their portfolio companies boards and in selecting board members. Therefore, by examining the relationship between the amount of $\mathrm{VC}$ funding and board appointment and activity, strategy and investment decisions we conjecture that VCs effects at the top of the company will grow as the amount of VCs 
funding into a company grows. We have addressed these issues through specific questionnaire items that we have modeled as the following dependent variables for which we expect a positive relationship with the size of the VC capital contribution: Board decisions (BODD), Board appointments (BODA), Strategy direction (STR), and Investment planning $(I N V)$. As a control, we have developed a variable (STRATEGY) capturing the broad Strategy Direction by averaging out the results for these four items. The Cronbach's alpha for this construct is .81 with inter item correlations from .76 to .84 .

Gorman and Sahlman (1989) and Sahlman (1990) suggested that the value of VC lies in providing not only money but also supplementary services, such as hiring executives. Similarly, Baker and Gompers (2003) looking at the top of the company, find that $\mathrm{VC}$ influence the selection of CEOs, and intervene in shaping top executive compensation policies. Bruton et al. (1998), Hellmann and Puri (2000, 2002), show that VCs are influential not only at the top of the organization, but also in the developments further down the organization. These scholars show that $\mathrm{VC}$ has a significant role also in designing Human Resources practices, employee incentive settings, shaping business strategies, and the investment planning process. Baker and Gompers (1999) provide evidence that VCs are actively involved in shaping employee incentives. According to Hellmann and Puri (2002), the development of human resource functions including employment security, incentive pay, promotion, skill development and training programs is an important aspect of the professionalization of VC-backed firms. In extending these findings, we expect these influences to be positively related to the amount of capital provided. We address these issues by modeling four additional variables: CEO hiring (CEO), Executive Compensation (EXE), HR practices (HR), Employee Incentives (EE).

Similarly to what we have done for the STRATEGY construct, we have developed a variable (HRP) capturing the influence of VCs on Human Resource Practices by averaging out the results for the four items. The Cronbach's alpha for this construct is .70 with inter item correlations from .69 to .78 , hence acceptable. Finally, we test the reliability of the overall survey by developing a comprehensive Governance variable (GOV) by averaging out all 8 items. The Cronbach's alpha for this construct is .82 with item correlations ranging from .52 to .79 which supports our research design. 
One of the important contributions of this paper is the much higher level of granularity of our governance items. Although working with single-items is generally less reliable, the previously reported analysis supports this approach. Accordingly, in the following section we will focus our analyses on the the single-item measures and report estimates for the aggregate measures in the Appendix.

Following Sapienza et al. (1995, 1996), Helmann and Puri (2000,2002), Schwienbacher (2008), Suchard (2009) we have extracted from VentureXpert, EVCA and NVCA the following supplemental control variables that have proven to be correlated with governance decisions: age, size, stage of development, industry and geographic location of headquarters and subsidiaries. Age (LnAge) is captured by the age from the inception date of the company, whereas the size is proxied by the number of employees working in the company (Ln\#Employees). Differently from most academic studies, we have ruled out cash revenues as a size proxy since most VC-backed companies are young and fast growing and their organizational structure is often designed after expected revenues rather than actual revenues, thus making cash revenues comparisons inconsistent. The age and size variables are transformed into their natural logarithmic form to allow better regression treatment. This appears as a consistent transformation when data are right skewed and lower bounded by zero as in our sample. We have also run control regressions with the absolute values for these variables without obtaining significantly different results. Stage of development is modeled through the following dummy variables: Startup, Expansion, and Later Stage. Industry classification follows North American Industry Classification Standard. Following Gompers and Lerner (2004) evidence on the average industry distribution of VC investments, we have classified sample companies according to three dummy variables that allow statistically significant grouping: Computer, Medical, and Other which will allow us to control for specific industry effects. Industries in the 'Other' category are Telecom, Electronics, Media, Financial Services, Non-financial Services, Manufacturing Light or Heavy, Mining Metals, Retail/Wholesale, Consumer Products, Agriculture, and Security. Finally we addressed geographical location by classifying firms with regards to the geographical area in which the corporate headquarters are located. ${ }^{\mathrm{ix}}$ In particular we model two 
dummy variables taking the value of 1 if the company is located, respectively in US or EU and 0 otherwise.

Table 1 reports the collected variables with the last column 'Source' indicating whether the variable has been obtained through VentureXpert (VX), EVCA (X/E), $\operatorname{NVCA}(\mathrm{X} / \mathrm{N})$ or through the questionnaire $(\mathrm{Q})$.

\section{INSERT TABLE 1 HERE}

$H R, E X E, E E, B O D D, B O D A, C E O, I N V, S T R$ are the previously specified dependent variables, $V C \%$ is the proportion of $\mathrm{VC}$ financing received as stated by questionnaire respondents. \# of VCs is a syndication control variable as in Lerner (1994a), capturing the number of different investors for each company in the sample horizon. This figure is collected from our survey data but we specifically cross-check with information on VentureXpert database: if data provided by the respondent is not consistent with publicly available information, we adopt the VentureXpert figure since literature on questionnairebased data collection suggest a higher probability of mistakes by the respondent rather than public database inaccuracy. This data consistency check resulted in ten changes.

To control for possible collinearity problems we present in table 2 the Covariance Matrix, that doesn't suggest significant risks of misspecification.

\section{INSERT TABLE 2 HERE}

We perform and describe further collinearity tests in the regression analysis section.

\section{Summary statistics}

Table 3 reports variables descriptive statistics for the Full sample and the European and American sub-samples. ${ }^{\mathrm{x}}$

INSERT TABLE 3 HERE 
Given the heterogeneity of the information collected it is difficult to compare our dataset against an existing public information source. However, to ensure sample representativeness we compare our main summary statistics with those presented in the most relevant extant literature. With regards to the size of the sample, we survey 164 ventures. This figure is in line with datasets in: Cumming and Zambelli (2010) reporting 162 transactions, Cumming (2009) investigating 223 companies, Hellmann (2000, 2002) reporting 173 respondents, Sapienza $(1996,1995)$ with 221 respondents. Finally, Hege and Palomino (2009) in a cross-sectional study of European VC-backed companies assemble a dataset of 146 companies. Our survey results indicate that $65 \%$ of the VCbacked companies are currently in the expansion stage of development, while about $24 \%$ of the VC-backed companies are startups. Only $11 \%$ of our sample companies identify their stage of development as later stage. Our figures are very close to those reported by the US venture capital association (NVCA) and European Venture Capital Association (EVCA) and reported in the PriceWaterhouseCoopers MoneyTree annual reports and EVCA/PWC Annual reports. In particular, the MoneyTree stage breakdown indicate a distribution across investment stages of $20 \%, 52 \%$ and $28 \%$ for the early stage/start-up, expansion and later stages in the US and 14\%, $71 \%$ and $15 \%$ for Europe. We reckon that the identification of the stage of investment may not be straightforward due to difference in the way data providers collect data, investors report their deals and VC-backed companies understand their stage. However the alignment of our survey figures with the aggregate data provides support to the sample representativeness. The average ownership by $\mathrm{VC}$ investors in our data is $70.35 \%$ with very large variation within sample and a larger mean stake in the US vs Europe, although this difference is not statistically significant. These figures are larger than those in Cumming (2009) who reports a median ownership by outside investors of $51 \%$ but with a dispersion similar to ours. Differently, Kaplan and Stromberg (2003) report a non-founders stake for VC-backed companies of approximately $70 \%$ before the IPO and $75 \%$ at the IPO time that is very close to ours. Target companies and investors' behavior show meaningful regional differences. On one hand, consistent with evidence by Hege et al. (2009), US VC-backed companies tend to be smaller, younger and with a higher frequency of start-ups. The average age in our sample is 6 years with statistically significant older companies in Europe (6.8 years) than 
in the US (5.4). this figure is comparable to that of Ivanov and Xie (2010) who report an average age of 6 years and, for the US subsample is slightly lower than that in Hellmann and Puri $(2000,2002)$ who report in their US surveys a mean age of 6.6 years. $59 \%$ of US investments in our sample targets high-growth industries such as medical and computer, while European ventures are more fragmented with almost $55 \%$ of the companies belonging to non-high tech industries. Our figures are aligned with those in Gompers et al (2008) whose sample reports $35 \%$ of companies in the computer related business, $21 \%$ in the medical industry and $44 \%$ in non-high tech industry and are comparable with those reported in the NVCA and EVCA national surveys. On the other hand, US Investors are more likely to syndicate as the average number of investors in a company is almost 4.5 as opposed to a European average of 3 and to acquire larger stakes in the target companies. These results are strongly aligned with those reported in a crosssectional analysis by Hege et al. (2009) who report figures of 3.7 and 2.8 for the US and Europe respectively.

Descriptive statistics of the dependent variables collected through our survey give a first hint at the existence of regional patterns. $37 \%$ of the companies in the US subsample have experienced a CEO replacement, while the figure drops to $31 \%$ in Europe. The US figure is very close to that in Schwienbacher (2008) who reported a 34\% replacement rate, while it's higher in our sample for European companies as Schwienbacher reports a $22 \%$ replacement rate. European companies express a perception of stronger influence by VC investors on the Strategy direction of the firm and Human resource practices other than CEO-related while differences are not significant for the other variables.

\section{EMPIRICAL TESTS}

\section{Methodology}

Given this sample composition we follow a three steps approach: firstly, we analyze the full set of polychotomous governance items through a set of standard OLS regressions to understand the relationship between the amount of $\mathrm{VC}$ funding and the perceived $\mathrm{VC}$ influence on the set of dependent variables in univariate and multivariate analyses. 
Secondly, we run a set of logit regressions on the CEO-replacement variable; Finally, we perform a battery of ordinal multinomial logistic regressions to interpret the economic significance of the response variables. We form our set of equations as follows:

Equation (1) aims at capturing the linear relationship between the amount of VC funding and $\mathrm{VC}$ influence in the full and geographical samples for every $i$ independent variable included in our analysis.

$$
y_{i}=\alpha+\beta X+\varepsilon
$$

where $y_{i}$ are the 8 dependent variables, $X=\left\{x_{1}, \ldots, x_{m}\right\}$ is the vector of the $m$ independent variables and $\beta$ is the vector of parameters.

Equation (2) estimates the log probabilities of the dependent variable outcome according to a standard multinomial logit regression where the univariate case is easily determined by setting $\mathrm{K}=1$ :

$$
\operatorname{Pr}\left(y_{n}=k\right)=\frac{\exp \left(X_{n} \beta_{k}\right)}{1+\sum_{k}^{K} \exp \left(X_{n} \beta_{k}\right)}
$$

where $X_{n}$ is the $m$-size vector of independent variables observed for every dependent variable $n, \beta$ is the vector of maximum likelihood parameters and $y_{n}$ are the different categorical responses of the dependent variable.

When dealing with variables characterized by multiple ordered responses, the previous model becomes:

$$
\operatorname{Pr}\left(y_{n}<k\right)=\frac{\exp \left(X_{n} \beta_{k}\right)}{1+\sum_{k}^{K} \exp \left(X_{n} \beta_{k}\right)}
$$

In all models standard errors are computed as Huber-White robust standard errors to allow asymptotically unbiased results, without having to assume homoskedasticity and normality of the random error terms. Given that we also introduce dummies for the most likely cluster levels we believe this approach provides consistent estimations. We have 
also performed tests regressions clustering data at the country, industry and stage level without observing significant differences in the estimated variance.

\section{Empirical results}

Full-sample OLS results. In univariate and multivariate OLS regressions on the full sample we find that the percentage of $\mathrm{VC}$ funding is statistically significant in explaining the variance in $\mathrm{VC}$ influence in the governance of firms. VIF tests return a maximum value of 1.35 thus allowing to rule out the existence of severe collinearity issues. In Table 4 we report detailed results for the full sample. Regression analyses using the three constructs GOV, STRATEGY and HRP are reported in the Appendix, Table A2 and are qualitatively and quantitatively aligned with estimates in Table 4.

\section{INSERT TABLE 4 HERE}

As the percentage of funding increases, VCs' influence on CEO hiring, executive compensation, employees incentives, board decisions, and board appointments grows accordingly. As shown by Gompers (1995), VC investors frequently require seats in the board of directors of portfolio companies as a monitoring covenant, since this allows better access to information and ongoing oversight on managerial decision-making. Confirming this seminal evidence, we observe the proportion of funding and influence on board decisions and appointments to be highly significant $(\beta=0.662 \mathrm{p}<0.01$ and $\beta=0.852$ $\mathrm{p}<0.001)$.

$\mathrm{VC}$ is a well-known case of principal-agent problem where the $\mathrm{VC}$ as a principal is exposed to large moral hazard issues not only by entrepreneurs but by a larger workforce which can be critical to the success of the venture. In such a case incentive alignment mechanisms such as profit sharing and pay-per-performance plan can be useful in reducing risk. This effect should be larger the larger the investment by the VC. Our results confirm this prediction showing that executive compensation $(\beta=0.716 \mathrm{p}<0.01)$ and incentives to employees $(\beta=0.504 \mathrm{p}<0.05)$ are positively and significantly linked to the proportion of VC funding received. 
On the other side, our full sample results do not provide conclusive support for VC firms having an impact on the broader issue of setting HR practices. In a univariate setting we find no significance while in a multivariate setting the proportion of VC funding becomes weakly significant alongside the syndication and stage variables. This latter result can be interpreted as confirmation of the theoretical model by Hellman (1998) who showed that since entrepreneurial companies are highly human capital intensive, investors will devote particular attention to the design of HR practices so to retain and foster that very capital. However, the HR model returns also a positive and significant parameter for the regional control variable $(\beta=0.217, p<0.1)$ that suggests the existence of differences across regions. We will address this issue in more detail in the section on ordinal logit tests.

Similar results are obtained for the strategy and investment planning variable. Our results do not provide evidence of a relationship with any of the explanatory and control variables for the investment planning measure. Differently, strategies seem to be determined more by the existence of large syndicates when companies are young but relatively larger. This outcome may be interpreted as supporting our third hypothesis. Larger firms are more likely to be syndicated (Gompers and Lerner, 2006) and when syndication occurs a significant amount of time is devoted to strategy design as this is likely a factor in attracting investors to the syndicate. Our full sample results confirm this interpretation, showing that companies in the start-up stage, with larger syndicates and a larger number of employees report higher influence by VCs in strategy direction.

Logit Regressions on CEO replacement. In Table 5 we present regression results for a set of univariate and multinomial models on the likelihood of the CEO to be replaced at the time of the $\mathrm{VC}$ investor capital infusion. The first and second columns report results for the univariate and multinomial tests on the full sample $(\beta=1.188 p<0.1$; $\beta=1.764, p<0.05)$ and confirm the theoretical prediction in Hellmann (1998), and the evidence in Lerner (1995), Bruton et al. (1997, 2000). Interestingly, in the multinomial setting, Age is significant in capturing variation in the dependent variable $(\beta=0.969$ $\mathrm{p}<0.01$ ). In columns 3 and 4 we report results for regressions on the US and European sub-samples respectively. ${ }^{x i}$ The size of the parameter increases twofold and significance 
for the main explanatory variable is unchanged for the US sample $(\beta=2.385 p<0.01)$ providing further support to previous theoretical and empirical contributions. Put differently, there is no evidence of a similar phenomenon in European companies with Age being the only significant factor. In particular when Age increases by one year the likelihood of a replacement in European companies increases by $13.2 \%$.

Full sample ordinal logistic regressions results. Menard (1995) among others, show that both OLS and logistic models can be used for analyzing categorical outcomes obtaining useful inferences for classification and hypothesis testing. However, OLS estimations have two features that require adequate care: first, OLS by construction yields predicted values beyond the constrained range of a categorical variable; second it implies that the effects of a change in the independent variable are constant, regardless of the starting point of the change and the level of the other (if any) independent variables. Since categorical models are nonlinear, estimations by OLS may be inaccurate for some levels of the independent variables. We overcome this problem by adopting an ordinal multinomial logistic regression approach to further investigate the effect of $\mathrm{VC}$ investments on a set of governance items and to provide a more accurate economic interpretation.

Table 6 reports the results of a set of ordinal logistic regressions for the full sample and the American and European sub-samples. Regression analyses using the three constructs GOV, STRATEGY and HRP are reported in the Appendix, Table A3 and are qualitatively and quantitatively aligned with estimates in Table 6 .

\section{INSERT TABLES 6 ABOUT HERE}

In all regressions the baselines are: US as a region so to capture the differential features of European target companies, the "Other" industry category in order to highlight effects of specific industries and the "Start-up" stage and the "High influence" response category. Since the dependent variable is a categorical measure ranging from 1 ("no influence") to 4 ("high influence") a positive estimated parameter can be interpreted 
as the independent variable being positively correlated with the perceived influence on the dependent variable.

The full sample results reported in Panel A are aligned with the OLS estimations and significance increase for the overall model and for the estimated parameters. The economic interpretation of the parameters is as follows: for a $1 \%$ increase above the mean value in VC stake, investors are approximately $0.9 \%$ more likely to exert a high influence on CEO hiring, executive compensation, Board of Directors decisions and appointment. Differently, reducing the number of syndicate members from the sample mean of 3.7 to a single investor reduces the likelihood of high influence on strategy by approximately $28 \%$. ${ }^{\text {xi }}$ In Figure 1 we provide a graphical interpretation of these result plotting the predicted probabilities for the extreme response categories ( $1=$ 'No or low influence' and 4='High influence') for the four most significant dependent variables, namely: CEO hiring (CEO), Executive compensation (EXE), Board of Directors decisions (BODD) and Board of Directors appointment (BODA).

\section{INSERT FIGURE 1 HERE}

The dashed lines graph the predicted probabilities for the response category 1 for each variable while the solid lines graph the predicted probabilities for the response category 4. Estimations are computed for changes in the VC ownership stake keeping all other variables constant at their mean values. Due to the non-linear nature of categorical models the interpretation of this graph is not straightforward: each line represent the predicted probabilities of observing a high or low influence of the amount of VC invested on the selected independent variable. For instance, when the VC stake is at its mean value of 70.35\% looking at the effect on Board of Directors Appointment, the model predicts a probability of recording a high influence slightly below $60 \%$ compared with a probability for a low influence of less than 5\%. Probabilities are increasing in the $\mathrm{VC}$ amount for the high category and decreasing for the low one. It is worth noting that probabilities do not add to the unit as we have not plotted the intermediate response categories 2 and 3 . The plotted results provide also a useful way to interpret the ordinal logit parameters as they 
can be looked at as the slopes of the plotted lines at the mean values of all variables, which offers a neat view of the non-linearity of the results.

Pseudo-R-square values are low but aligned with results reported in the extant literature. Differently, Chi-square values indicate a generally good fit of the model in explaining the variations in the data. Specification link tests run on all regressions dismiss possible collinearity concerns.

Sub-Sample Results. The regional control dummy variable in our aggregate models suggests sharp differences in practices between the two regions. To capture this relevant information we partition our analysis into European and American sub-samples. The empirical results are reported in Panel B and C.

The sub-sample analysis validates hypothesis 2 showing a remarkable difference in European and US practices. ${ }^{\text {xiii }}$ First, in US VC-backed companies VC investment size is significant and positive in influencing almost all governance mechanisms with the exception of strategy, investment and HR, as previously observed through OLS analysis. The parameters increase in magnitude and significance as well as the overall fit of the regressions as captured by the increased distance in predicted probabilities reported in Figure 2.

\section{INSERT FIGURE 2 HERE}

Comparing this result with that reported in Figure 1 we notice that essentially all of the variation in the response for these items come from the US sub-sample. Differently, the European sub-sample results show that size is relevant only for Investment decisions and weakly for CEO hiring. Figure 3 plots the predicted probabilities for the 'High influence outcome' only for the most significant estimated parameters in Panels B and C, namely EXE and BODD for the US sub-sample and INV for the European sub-sample.

\section{INSERT FIGURE 3 HERE}


The graph shows that while investment decisions in the US are unaffected by VC ownership - as captured by the insignificant and close to zero estimated parameters and by the slightly negatively sloped line - they are positively affected in Europe by the increase of the investor's stake in the magnitude of about $10 \%$ per one standard deviation. Differently, while a change in VC ownership in US companies from the minimum value to the maximum value increases the likelihood of a high influence on executive compensation and Board of directors decisions by, respectively over $56 \%$ and $58 \%$, the same change on European companies translates into a change in predicted probabilities of only $19 \%$ and $3 \%$.

These mixed results can be explained following Bottazzi, da Rin and Hellmann (2003) arguments: due to differences in the development and professionalization of VC activity and to deeply rooted governance practices, European VCs are more focused on the evaluation of CEOs. This result complement the logit regression result on CEOreplacement reported in Table 5 that showed that in European companies existing CEOs are not significantly affected by the arrival of an outside $\mathrm{VC}$ investor. This evidence suggests that differently form US investors, European VC are limitedly keen on investing in a company where the CEO value is substantial but his management skills are such that a replacement is a pre-requisite to the investment decision.

Secondly, differently from previous aggregate results, we have a noteworthy industry and stage effect in Europe that is almost absent in the US. Inspecting the results we notice that investors in European firms exert a significant influence on the structure and decision of the Board of Directors and on executive compensation if the investment is targeted at a high risk industry such as Medical or Computer-related. In particular, investment in these two industries are associated with over 30\% greater likelihood of a strong influence on the BODD and EXE dependent variables than the 'Other' baseline case. Similarly, decisions on CEO hiring, human resources and HR practices are almost unaffected by the intervention of a VC investor if the company is at a later stage of development. The estimated parameters indicate that if the company is in a later stage, the likelihood of the VC to exert a "high influence" on decision drops by about $90 \%$. On the other hand, US evidence indicates no specific industry effect and only a stage effect on strategy decisions. We explain this result as evidence of the relative inexperience of 
the European Venture Capital industry and the lower level of R\&D and High-tech activity: European investors in high risk ventures try to exert a higher level of control on corporate decisions while they feel more confident if the investment is in a more traditional sector. This interpretation is supported also by the investment allocation figures in table 2, which indicate that European investments are much less concentrated in the two industries with the highest level of risk. ${ }^{\text {xiv }}$

The sharp difference observed in the two geographical areas are noteworthy since they signal a profound difference in the approach to venture investments that may significantly affect the efficiency of the relationship between investors and entrepreneurs. Our survey data do not allow an accurate test of the determinants of these striking differences. However, we argue that different regulation and standards in the two areas, unequal levels of institutionalization of VCs and the traditional availability in Europe of alternative - although not necessarily similarly efficient - financing channels such as banks, corporations and individuals may explain the estimated differences. These reasons allow conjecturing that the sharp discrepancies observed may reduce over time with the growth of the industry expertise, the increase in cross-border investing and the shift from traditional bank lending to risky capital for the support of new ventures. Yet, cultural, legal and accounting differences are less likely to quickly disappear suggesting a possible resilience of these differential governance practices in the future.

\section{DISCUSSION AND CONCLUSIONS}

Recent growth in the Venture Capital (VC) industry has stimulated new research exploring the structure of Venture Capital deals. Available evidence shows that VCs not only support firms with essential financing, but also provide value-added services to their portfolio companies aimed at monitoring the progress and the strategy of firms. While we now know much more on the mechanics of this industry still we have limited knowledge on the effect of $\mathrm{VC}$ activity in shaping and managing the governance structure of portfolio companies conditional and unconditional on the size of the investment injected and on the geographical area of the portfolio company. In this paper, we try to fill this gap by testing the impact of differential levels of capital injection and different regions of incorporation of portfolio companies on a unique hand-collected questionnaire-based 
dataset from 164 companies in 5 countries. By using survey data we have been able to explore governance decisions at a deeper level of analysis than that allowed by data available through traditional providers. In designing the survey structure we have focused on a set of relevant and previously limitedly explored governance decisions in portfolio companies, in particular: CEO hiring and replacement, HR practices, executive compensation, employee incentives, board decisions, board appointments, strategy direction and investment plan design. Collected data have been tested through a two-fold econometric approach running both linear estimations and multinomial logit and ordinal logit techniques. Results indicate that as the proportion of $\mathrm{VC}$ funding into the companies increases, $\mathrm{VCs}$ ' influence on $\mathrm{CEO}$ hiring and replacement, Executive compensation, Board decisions, and Board appointments increases significantly. VC influence on executive compensation is consistent with the growing attention devoted to corporate governance issues in US more than other countries in the world. In addition, VC influence on employee incentives in portfolio companies is also significant and positively linked to the proportion of $\mathrm{VC}$ funding received. On the other side we document that VC firms are not strongly influential in HR practices, strategy direction and investment planning of their portfolio companies. Additionally, results indicate that the degree of syndication is of limited influence on most governance mechanisms and a substitute to VC investment size in influencing HR policies and target firms' strategies. This result suggests that by assigning a single $\mathrm{VC}$ the leading role and accordingly delegating the control and monitoring tasks, the syndication process make lead investors to act as lone investors thus generating the insignificance of results we have observed. Similarly, when investors cannot benefit from the portfolio diversification effect of syndication, they have an incentive in controlling more closely portfolio companies addressing more effectively sensitive corporate governance issues. However, we cannot rule out the possibility that our results are driven by the structure of VC syndicates: the distribution of ownership and the relative weight of the lead-investor as well as nonlinear effects of the number of syndicate members may play a role in driving the influence of VCs on the governance of firms. We anticipate this to be a fruitful area for future research. 
Significant differences emerge when comparing European and American venturebacked companies. In Europe only CEO hiring, and investment planning decisions are positively influenced by VCs proportion of funding with no evidence of significant effects of VC funding on other aspects of portfolio companies' governance. Differently, for the American sub-sample we provide consistent evidence that the proportion of VC funding is significant and positively related to $\mathrm{VC}$ influence in a much larger set of issues such as CEO hiring, executive compensation, employee incentives, board decisions, and board appointments but it is not significant to explain the variance in VC influence in HR practices, strategy direction and investment planning. An interesting result is the absence of any industry effect in the US as opposed to a strong effect in Europe, which indicate that investments in high-risk ventures such as in the medical or computer industry, are accompanied by a stronger intervention by investors on a larger number of governance issues. The suprising evidence on regional differences contribute to the ongoing development of a global theory of corporate governance. Many contributions have highlighted that agency-theory may fail to capture the degree of variation of international corporate governance practices due to non-negligible differences in legal systems, law enforcement, and cultural issues (La Porta et al, 1998; Denis and McConnell, 2003; Zattoni and Cuomo, 2008; Judge et al. 2010). Our results support this view as they suggest that the limited convergence of governance mechanisms may not necessarily be a signal of inefficiency but simply the response of firms and investors to different social, economic, and political environments in which different governance mechanisms are the optimal response to possibly different maximization problems. In fact, from an agency perspective our empirical evidence on US firms is largely aligned with theoretical predictions that would suggest a much larger and more pervasive degree of control on companies by outside investors. On the other hand, though, the European evidence seem more in line with the "functional convergence" view of Coffee (1999) and la Porta et al (2000) that propose that some governance practices may not be implemented, or be altogether inefficient (Khanna et al, 2002) in the presence of institutional differences. In such a case, alternative solutions such as informal mechanisms, social norms or international diversification may act as substitutes to explicit governance mechanisms. 
Our study provides a novel view of the functioning of the Venture Capital industry and its degree of pervasiveness in the management of portfolio companies. While furnishing further support to the idea that the incremental contribution of a professional investor to a new venture is largely exceeding the mere capital infusion, our study delivers relevant implications for both investors and investees. First, we document that governance mechanisms change conditional on a number of investment-specific factors, such as industry, stage and most importantly nationality. This last factor becomes particularly meaningful when dealing with cross-border investments. When investors and investees approaches to governance decisions are largely different, pre-investment negotiations may unravel more frequently, leading to a slower development of the VC industry and a lower growth rate of new ventures; similarly, once the investment is initiated, these differences may lead to conflicts in the management of the venture, ultimately leading to unsuccessful exits. Second, from an investee perspective, our evidence suggests the existence of a trade-off between the financial safety of a large capital injection by VC investors and the reduced chance of retaining control over the management of the venture. Insofar, this effect has proven to be of a lesser extent in Europe, however the increasing convergence between governance systems suggest that venture capitalists may be likely to require increasingly sophisticated governance rights also outside the US.

\section{Future Research}

Our study is a first attempt at shedding light on the effect of institutional investors on the inner governance of investees in a global market. As such, many issues are still unresolved and open up interesting avenues for future research. Given the sharp differences observed in the two regions, an obvious first research question is to dig deeper at the single country level. Our data do not yield interesting results when breaking down the sample at the single country level, thus preventing meaningful inferences on the effects of legal and cultural variables on the VCs influence the governance of portfolio companies. We are strongly convinced that this outcome is due to the survey nature of the study that limits the available datapoints for each country. A fruitful area of research would be to address this issue by either starting a more ambitious survey effort or 
possibly trying a meta-analysis approach to jointly investigate existing cross-country evidence. Secondly, when analyzing the VC influence on the governances of firms, we did not take into account whether or not this influence was a positive (supportive) or a negative (destructive) one. Extant literature addresses this issue by looking at the default rate and exit performance of companies. Following this approach, a higher influence of VCs in shaping portfolio companies strategies and management is considered positive if yielding a lower default rate and/or a higher return on exit. However, it is difficult to ascertain the value of the null hypothesis, i.e. if and how VC influence is a factor in selecting winners and losers in a sub-efficient way. A possible research strategy could be to adopt a propensity score matching approach by looking at companies that were potential recipient of $\mathrm{VC}$ funding and chose different financing routes such as business angels, individual investors, "friends and family", government programs, banks and corporate programs. Thirdly, an interesting question arises on the convergence of governance mechanisms: is convergence driven by demand or supply? VC is by-andlarge a local business, i.e. domestic investors still invest predominantly in their own countries. However, entrepreneurs are increasingly moving across countries, often following the best financing opportunities. In such a case it would be interesting to understand if, how and how quickly the entrepreneur-originated governance approach dominates or is dominated by that of the host country of the new venture and, arguably, the $\mathrm{VC}$ investor. 


\section{REFERENCES}

Admati, A. and Pfleiderer, P., 1994. Robust financial contracting and the role for venture capitalists, Journal of Finance, 49, 371-402.

Aggarwal, R., Erel, I., Stulz, R. and Williamson, R., 2009. Differences in Governance Practices between U.S. and Foreign Firms: Measurement, Causes, and Consequences, Review of Financial Studies, 22, 3131-3169.

Baker, M. and Gompers, P.A., 2003. The determinants of board structure at Initial Public Offering, Journal of Law and Economics, 46, 2, 569-598.

Baker, M. and Gompers, P., 1999. Executive Ownership and Control in Newly Public Firms: The Role of Venture Capitalists, Harvard University Working Paper.

Barry, C., 1994. New directions in venture capital research, Financial Management, 23, 3-15.

Bergmann, D. and Hege, U., 1998. Dynamic venture capital financing, learning, and moral hazard, Journal of Banking and Finance, 22-6, August, 703-735.

Bernile, G., Cumming, D., Lyandres, E., 2007. The Structure of Private Equity Fund Portfolios: Theory and International Evidence. Journal of Corporate Finance,4, 564590.

Bhattacharya, S. and Thakor, A., 1993. Contemporary banking theory, Journal of Financial Intermediation, 3, 2-50.

Bottazzi, L., Da Rin, M. and Hellmann, T., 2003. What defines financial intermediaries, their organizational structure of human capital?, Stanford University mimeo.

Bruton, G. D., Fried V. H., Hisrich R. D., 1997. Venture Capitalist and CEO Dismissal, Entrepreneurship: Theory and Practice, Vol. 21.

Bruton, G. D., Fried V. H., Hisrich R. D., 1998. Strategy and the board of directors in venture capital-backed firms, Journal of Business Venturing, 6, 493-503.

Bruton, G. D., Fried V. H., Hisrich R. D., 2000. CEO Dismissal in Venture CapitalBacked Firms: Further Evidence from an Agency perspective, Entrepreneurship: Theory and Practice, Vol. 24.

Bygrave, W. and Timmons, J., 1992. Venture capital at the crossroads, Boston, Massachusetts, Harvard Business School Press. 
Casamatta C. and Haritchabalet C., 2007. Experience, Screening and Syndication in Venture Capital Investments, Journal of Financial Intermediation, 16, 3, 368-98

Coffee, J. C., 1999. The Future as History: The Prospects for Global Convergence in Corporate Governance and its Implications, Northwestern University Law Review, 93, 641-708.

Cornelli, F. and Yosha, O., 2003. Stage Financing and the Role of Convertible Securities, Review of Economic Studies, 70

Cumming D. and Zambelli S., 2010, Illegal Buyouts, Journal of Banking and Finance, 34, 441-456.

Cumming D., Schmidt D., and Waltz U., 2010. Legality and Venture Capital Governance around the world, Journal of Business Venturing, vol 25, Issue 1

Cumming, D., 2006. The Determinants of Venture Capital Portfolio Size: Empirical Evidence, Journal of Business, 79, 1083-1126.

Cumming, D., 2005. Global Venture Capital Transactions, Venture Capital: An International Journal of Entrepreneurial Finance, 7, 2, 185 - 201.

Da Rin, M., Hege U., Liobet G. Walz U., 2006. The Law And Finance of Venture Capital Financing in Europe, European Business Organization Law Review, 7: 525-547

Dawes, J., 2008. Do Data Characteristics Change According to the number of scale points used? An experiment using 5-point, 7-point and 10-point scales, International Journal of Market Research, 50 (1), 61-77.

De Nicolo, G., Laeven, L. and Ueda, K., 2008. Corporate governance quality: Trends and real effects, Journal of Financial Intermediation, 17: 198-228.

Denis, D. \&McConnell, J., 2003. International corporate governance, Journal of Financial and Quantitative Analysis, 38: 1-36.

Diamond, D., 1984. Financial intermediation and delegated monitoring, Review of Economic Studies, 51, 393-414.

Dimov, D. and De Clercq, D., 2006. Venture Capital Investment Strategy and Portfolio Failure Rate: A Longitudinal Study, Entrepreneurship Theory and Practice, 30: 207223.

Doidge, C., A. Karolyi, and R. Stulz., 2007. Why Do Countries Matter so Much for Corporate Governance?, Journal of Financial Economics, 86, 1-39. 
EVCA, 2006. Private Equity Fund Structures in Europe, European Venture Capital Association.

Fama, E., 1985. What's different about banks?, Journal of Monetary Economics, 15,2939

Fama, E.F. and Jensen, M.C., 1983. Separation of ownership and control, Journal of Law and Economics, 26, 301-25.

Gompers, P., 1995. Optimal investment, monitoring, and the staging of venture capital, Journal of Finance, 50, 1461-1489.

Gompers P. and Lerner J., 2006. The Venture Capital Cycle, $2^{\text {nd }}$ Ed., MIT Press.

Gompers P., Kovner A., Lerner J., and Scharfstein D., 2008. Venture capital investment cycles: The impact of public markets. Journal of Financial Economics. 87, 1, 1-23.

Gorman, M. and Sahlman, W.A., 1989. What do venture capitalists do? , Journal of Business Venturing, 4, 231-48.

Grossman, S., and Hart, O., 1986. The costs and benefits of ownership: a theory of vertical and lateral integration, Journal of Political Economy, 94, 691-719.

Hege U., Palomino F., and Schwienbacher A., 2009. Venture Capital Performance: The Disparity Between Europe and the United States, Finance, May 2009, p. 7-50.

Hellmann, T., 1998. The allocation of control rights in venture capital contracts, Rand Journal of Economics, 29, 1, 57-76.

Hellmann, T. and Puri, M., 2000. The interaction between product market and financing strategy: The role of venture capital, Review of Financial Studies, 13 (4), 959-984.

Hellmann, T. and Puri, M., 2002. Venture capital and the professionalization of start-up firms: Empirical evidence, Journal of Finance 57 (1), 169-197.

Hochberg, Y., 2004. Venture Capital and Corporate Governance in the Newly Public Firm, Stanford University Mimeo.

Hochberg, Y., Ljungqvist, A. and Lu, Y., 2007. Who you know matters: Venture capital networks and investment performance, Journal of Finance, 62, 1, 251-301.

Hopt, K. and Leyens, P., 2004. Board Models in Europe - Recent Developments of Internal Corporate Governance Structures in Germany, the United Kingdom, France, and Italy, ECGI - Law Working Paper No. 18/2004. 
Ivanov, V. I. and Xie, F. , 2010., Do Corporate Venture Capitalists Add Value to StartUp Firms? Evidence from IPOs and Acquisitions of VC-Backed Companies, Financial Management, 39: 129-152.

Jääskeläinen M., 2009. Venture capital syndication: synthesis and future directions, Helsinki University of Technology Report 2009/1.

Jääskeläinen, M., Maula, M. and Seppä, T., 2006. Allocation of Attention to Portfolio Companies and the Performance of Venture Capital Firms, Entrepreneurship Theory and Practice, 30: 185-206.

Jensen, M. C. and Meckling, W.H., 1976. Theory of the firm: Managerial behavior, agency costs and ownership structure, Journal of Financial Economics, 3, 305-360.

John, K., and Kedia, S., 2006. Institutions, Markets and Growth: A Theory of Comparative Corporate Governance, Working Paper, New York University.

Judge, W. Q., Gaur, A., Muller-Kahle, M., 2010. Antecedents of Shareholder Activism in Target Firms: Evidence from a Multi-Country Study, Corporate Governance: an International Review, 18, 4, 258-273.

Kanniainen, V, and C. Keuschnigg C., 2003. The Optimal Portfolio of Start-up Firms in Venture Capital Finance, Journal of Corporate Finance, 9, 521-534.

Kanniainen, V., and Keuschnigg C., 2004. Start-up Investment with Scarce Venture Capital Support, Journal of Banking and Finance, 28, 8, 1935-1959.

Kaplan, S., Sensoy B., Strömberg P., 2002. How Well Do Venture Capital Databases Reflect Actual Investments, Working Paper, University of Chicago.

Kaplan, S. and Stromberg, P., 2000. How do venture capitalists choose and manage their investments, University of Chicago working paper.

Kaplan, S. and Stromberg, P., 2003. Financial contracting theory meets the real world: Evidence from venture capital contracts, Review of Economic Studies, 70 2, 281-315.

Kaplan, S. and Stromberg, P., 2004. Characteristics, Contracts, and Actions: Evidence From Venture Capitalist Analyses, Journal of Finance, 59, 5, 2177-2210.

Khanna, T., Kogan, J. and Palepu, K., 2006. Globalization and dissimilarities in corporate governance: A cross-country analysis, The Review of Economics and Statistics, 88: 6990.

Kotha, R., 2008. Equity traps: The distribution of cash flow incentives among investors 
in venture capital syndicates and performance of start-ups. SSRN, abstract ID 1115050. Kroszner, R.S. and Strahan, P.E., 2001. Bankers on Boards: Monitoring, Conflicts of Interest, and Lender Liability, Journal of Financial Economics, 62 (3): 415-52.

La Porta R., Lopez-de-Silanes F., Shleifer A. Vishny, R., 1998. Law and Finance, Journal of Political Economy, 106, 1113-1155.

La Porta R., Lopez-de-Silanes F., Shleifer A. Vishny, R., 2000. Investor Protection and Corporate Governance, Journal of Financial Economics, 58, 3-27.

La Porta R., Lopez-de-Silanes F., and Shleifer A., 2008. The economic consequences of legal origin, The Journal of Economic Literature, 46, 2, 285-332.

Lerner, J., 1994a. The syndication of venture capital investments, Financial Management, 23, 16-27.

Lerner, J., 1994b. Venture capitalists and the decision to go public, Journal of Financial Economics, 35, 293-316.

Lerner, J., 1995. Venture capitalists and the oversight of private firms, Journal of Finance, 50, 301-318.

Manigart, S. and Sapienza, H. J., 2000. Venture capital and growth, The Blackwell Handbook of Entrepreneurship, Oxford, Blackwell Publishers.

Mäkelä, M.M., Maula, M.V.J., 2006., Interorganizational commitment in syndicated cross-border venture capital investments, Entrepreneurship Theory and Practice, 30, 2, 273-298.

Menard, S., 1995. Applied Logistic Regression Analysis, Quantitative Applications in the Social Sciences. Sage Publications.Series, No. 106.

Sahlman, W.A., 1990. The structure and governance of venture capital organizations, Journal of Financial Economics, 27, 473-524.

Sapienza, H. J., Manigart, S. and Vermeir, W., 1995., A comparison of venture capitalist governance and value-added in the U.S. and Western Europe, Academy of Management Journal Papers, 105-109.

Sapienza, H. J., Manigart, S. and Vermeir, W., 1996. Venture Capital Governance and Value Added in Four Countries, Journal of Business Venturing, 11, 439-469.

Schwienbacher A., 2008. Venture Capital Investment Practices in Europe and in the United States, Financial Markets and Portfolio Management, 22 (3), 195-217. 
Shleifer, A. \& Vishny, R., 1997. A survey of corporate governance. The Journal of Finance, 52: 737-783.

Stiglitz, J. E., 1985. Credit Markets and the control of capital, Journal of Money, Credit and Banking, 17 133-152.

Suchard, J. A., 2009. The Impact of Venture Capital Backing on the Corporate Governance of Australian Initial Public Offerings, Journal of Banking and Finance, 33, $765-774$

Teoh, S. H., I. Welch, Wong T., 1998. Earnings Management and the Long-Run Performance of Initial Public Offerings, The Journal of Finance, 53, 1935-1974.

Tian X., 2008. The Role of Venture Capital Syndication in Value Creation for Entrepreneurial Firms, EFA 2007 Ljubljana Meetings Paper.

Van den Berghe L.A.A., Levrau A., 2002. The Role of the Venture Capitalist as Monitor of the Company: a corporate governance perspective, Corporate Governance: An International Review, 10, 3, 124-135

Williamson, O.E., 1983. Organization form, residual claimants, and corporate control, Journal of Law and Economics, 26, 351-66.

Yoshikawa T. and Rasheed A. A., 2009. Convergence of corporate governance: critical review and future directions, Corporate Governance: an International Review, 17, 3, 388-404.

Young, M.N., Peng, M., Ahlstrom, D. \& Bruton, G., 2002. Governing the Corporation in Emerging Economies: A Principal-principal Perspective, Best Paper Proceedings, Academy of Management Annual Meeting.

Zattoni, A. and Cuomo, F., 2008. Why adopt codes of good governance? A comparison of institutional and efficiency perspectives, Corporate Governance: An International Review, 16: 1-21.

Zingales, L., 1995. What determines the value of corporate votes? The Quarterly Journal of Economics, 110, 1047-73 


\section{Table 1 \\ Variables Description}

This table provides description of the variables collected through a questionnaire administered to 500 companies which received VC financing, supplemented by additional information gathered from different sources. The first column reports the specific variable, the second column summarizes the information conveyed by the variable, the 'Source' Column indicates whether the item has been obtained from VentureXpert (VX), EVCA $(\mathrm{X} / \mathrm{E})$, NVCA $(\mathrm{X} / \mathrm{N})$ or through the questionnaire $(\mathrm{Q})$.

\begin{tabular}{|c|c|c|}
\hline Variable & Description & Source \\
\hline$V C \%$ & $\begin{array}{l}\text { is the proportion of } \mathrm{VC} \text { financing (of total financing) that is received by the firm. This variable takes a value } \\
\text { between } 0 \text { and } 100 \text { and described as in percentage terms. }\end{array}$ & Q \\
\hline \#ofVCs & is the number of different VC firms that have financed each of our sample firms for the last five years. & Q \& VX \\
\hline $\operatorname{Age}(\operatorname{Ln} A G E)$ & is the age (natural logarithm of age) of the firm in years. & $\mathrm{Q}, \mathrm{VX}, \mathrm{X} / \mathrm{E}, \mathrm{X} / \mathrm{N}$ \\
\hline $\begin{array}{l}\text { Number of } \\
\text { employees }(\operatorname{Ln} \# E E)\end{array}$ & is the absolute number (natural logarithm) of the number of full-time employees working in the firm. & $\mathrm{Q}, \mathrm{VX}, \mathrm{X} / \mathrm{E}, \mathrm{X} / \mathrm{N}$ \\
\hline CEO-replaced & is a dummy variable taking the value of 1 if the company has repaced the CEO after receiving VC funding & Q \\
\hline CEO & $\begin{array}{l}\text { is a 4-point Likert scale variable that is described by a rate going from } 1 \text { to } 4 \text { that the firm reported that the venture } \\
\text { capitalists are influential in CEO hiring decisions of the firms ( } 1=\text { no influence and } 4=\text { high influence). }\end{array}$ & Q \\
\hline$H R$ & $\begin{array}{l}\text { is a 4-point Likert scale variable that is described by a rate going from } 1 \text { to } 4 \text { that the firm reported that venture } \\
\text { capitalists are influential in deciding overall human resource policies ( } 1=\text { no influence and } 4=\text { high influence). }\end{array}$ & Q \\
\hline$E X E$ & $\begin{array}{l}\text { is a 4-point Likert scale variable that is described by a rate going from } 1 \text { to } 4 \text { that the firm reported that venture } \\
\text { capitalists are influential in deciding the level of executive compensation ( } 1=\text { no influence and } 4=\text { high influence). }\end{array}$ & Q \\
\hline INCENT & $\begin{array}{l}\text { is a 4-point Likert scale variable that is described by a rate going from } 1 \text { to } 4 \text { that the firm reported that venture } \\
\text { capitalist are important in determining employees (other than CEO) incentives. ( } 1=\text { no influence and } 4=\text { high } \\
\text { influence). }\end{array}$ & Q \\
\hline$B O D D$ & $\begin{array}{l}\text { is a 4-point Likert scale variable that is described by a rate going from } 1 \text { to } 4 \text { that the firm reported that the venture } \\
\text { capitalists are influential in takeover decisions of board of directors ( } 1=\text { no influence and } 4=\text { high influence). }\end{array}$ & Q \\
\hline$S T R$ & $\begin{array}{l}\text { is a 4-point Likert scale variable that is described by a rate going from } 1 \text { to } 4 \text { that the firm reported that the venture } \\
\text { capitalists are influential in strategy direction of the firms ( } 1=\text { no influence and } 4=\text { high influence). }\end{array}$ & Q \\
\hline$B O D A$ & $\begin{array}{l}\text { is a 4-point Likert scale variable that is described by a rate going from } 1 \text { to } 4 \text { that the firm reported that the venture } \\
\text { capitalists are influential in board of directors' appointments of the firms ( } 1=\text { no influence and } 4=\text { high influence). }\end{array}$ & Q \\
\hline$I N V$ & $\begin{array}{l}\text { is a 4-point Likert scale variable that is described by a rate going from } 1 \text { to } 4 \text { that the firm reported that the venture } \\
\text { capitalists are influential in investment planning of the firms ( } 1=\text { no influence and } 4=\text { high influence). }\end{array}$ & Q \\
\hline Computer & is a dummy variable that takes the value 1 if the company is in computer related industry and 0 otherwise. & $\mathrm{Q}, \mathrm{VX}, \mathrm{X} / \mathrm{E}, \mathrm{X} / \mathrm{N}$ \\
\hline Medical & is a dummy variable that takes the value 1 if the company is in medical industry and 0 otherwise. & $\mathrm{Q}, \mathrm{VX}, \mathrm{X} / \mathrm{E}, \mathrm{X} / \mathrm{N}$ \\
\hline Other & is a dummy variable that takes the value 1 if the company is in other industry not computer or medical & $\mathrm{Q}, \mathrm{VX}, \mathrm{X} / \mathrm{E}, \mathrm{X} / \mathrm{N}$ \\
\hline Startup & is a dummy variable that takes the value 1 if the company is currently in startup and early stage of operations. & $\mathrm{Q}, \mathrm{VX}, \mathrm{X} / \mathrm{E}, \mathrm{X} / \mathrm{N}$ \\
\hline Expansion & $\begin{array}{l}\text { is a dummy variable that takes the value } 1 \text { if the company is currently in expansion and development stage of } \\
\text { operations. }\end{array}$ & $\mathrm{Q}, \mathrm{VX}, \mathrm{X} / \mathrm{E}, \mathrm{X} / \mathrm{N}$ \\
\hline Later & is a dummy variable that takes the value 1 if the company is currently in later stage & $\mathrm{Q}, \mathrm{VX}, \mathrm{X} / \mathrm{E}, \mathrm{X} / \mathrm{N}$ \\
\hline $\boldsymbol{U S}$ & is a dummy variable that takes the value 1 if the company is located in America and 0 otherwise. & $\mathrm{Q}, \mathrm{VX}, \mathrm{X} / \mathrm{E}, \mathrm{X} / \mathrm{N}$ \\
\hline $\boldsymbol{E} \boldsymbol{U}$ & is a dummy variable that takes the value 1 if the company is located in Europe and 0 otherwise. & $\mathrm{Q}, \mathrm{VX}, \mathrm{X} / \mathrm{E}, \mathrm{X} / \mathrm{N}$ \\
\hline
\end{tabular}




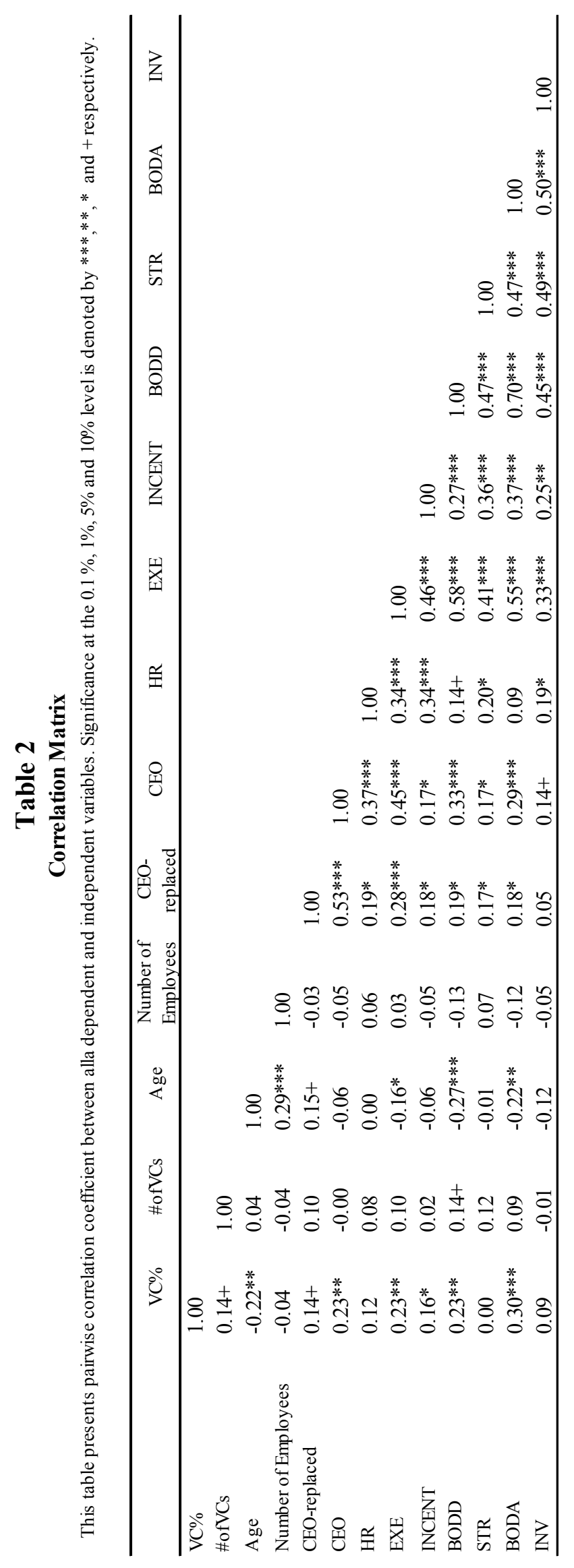




\section{Table 3}

\section{Descriptive Statistics}

This table presentes summary statistics for the dependent and independent variables for the Full sample and European vs US subsamples. Variable description is specified in Table 1. Differences between European and US data is tested by a onetailed t-test for numerical variables. Differences between European and US data is tested by Pearson's Chi-squared test for categorical variables. Significance at the $0.1 \%, 1 \%, 5 \%$ and $10 \%$ level is denoted by $* * *, * *, *$ and + respectively.

\begin{tabular}{|c|c|c|c|c|c|c|c|}
\hline \multirow[b]{2}{*}{ Variables } & \multicolumn{2}{|c|}{ Full Sample } & \multicolumn{2}{|c|}{ US } & \multicolumn{2}{|c|}{ EU } & \multirow{2}{*}{$\begin{array}{l}\text { Diff US/EU } \\
\text { Diff. }\end{array}$} \\
\hline & Mean Value & StDev & $\begin{array}{l}\text { Mean } \\
\text { Value }\end{array}$ & StDev & $\begin{array}{l}\text { Mean } \\
\text { Value }\end{array}$ & StDev & \\
\hline $\mathrm{VC} \%$ & 70.35 & 27.19 & 72.11 & 28.89 & 68.60 & 25.43 & 3.51 \\
\hline Age & 6.00 & 4.44 & 5.44 & 3.65 & 6.81 & 5.05 & $-1.37^{*}$ \\
\hline Number of Employees & 101.67 & 320.14 & 72.83 & 134.05 & 130.51 & 431.96 & -57.68 \\
\hline \#ofVCs & 3.74 & 3.27 & 4.42 & 3.74 & 3.06 & 2.58 & $1.35 * * *$ \\
\hline StartUp & 0.24 & & 0.29 & & 0.20 & & 0.50 \\
\hline Expansion & 0.65 & & 0.57 & & 0.72 & & -0.20 \\
\hline Later & 0.11 & & 0.13 & & 0.09 & & 0.58 \\
\hline Computer & 0.29 & & 0.33 & & 0.24 & & 0.35 \\
\hline Medical & 0.24 & & 0.27 & & 0.21 & & 0.29 \\
\hline Other & 0.48 & & 0.40 & & 0.55 & & -0.27 \\
\hline CEO-replaced & 0.34 & & 0.37 & & 0.32 & & 0.15 \\
\hline $\mathrm{CEO}$ & 2.69 & 1.29 & 2.73 & 1.35 & 2.65 & 1.24 & 0.09 \\
\hline HR & 1.98 & 0.84 & 1.89 & 0.75 & 2.06 & 0.91 & $-0.17+$ \\
\hline EXE & 3.23 & 0.84 & 3.29 & 0.75 & 3.17 & 0.93 & 0.12 \\
\hline INCENT & 2.44 & 0.87 & 2.42 & 0.89 & 2.46 & 0.86 & -0.05 \\
\hline BODD & 3.55 & 0.78 & 3.61 & 0.77 & 3.49 & 0.79 & 0.12 \\
\hline STR & 3.02 & 0.82 & 2.87 & 0.81 & 3.17 & 0.80 & $-0.31 * *$ \\
\hline BODA & 3.43 & 0.78 & 3.45 & 0.74 & 3.40 & 0.81 & 0.05 \\
\hline INV & 3.05 & 0.88 & 2.99 & 0.90 & 3.11 & 0.86 & -0.12 \\
\hline Total Obs & 164 & & 82 & & 82 & & 164 \\
\hline
\end{tabular}




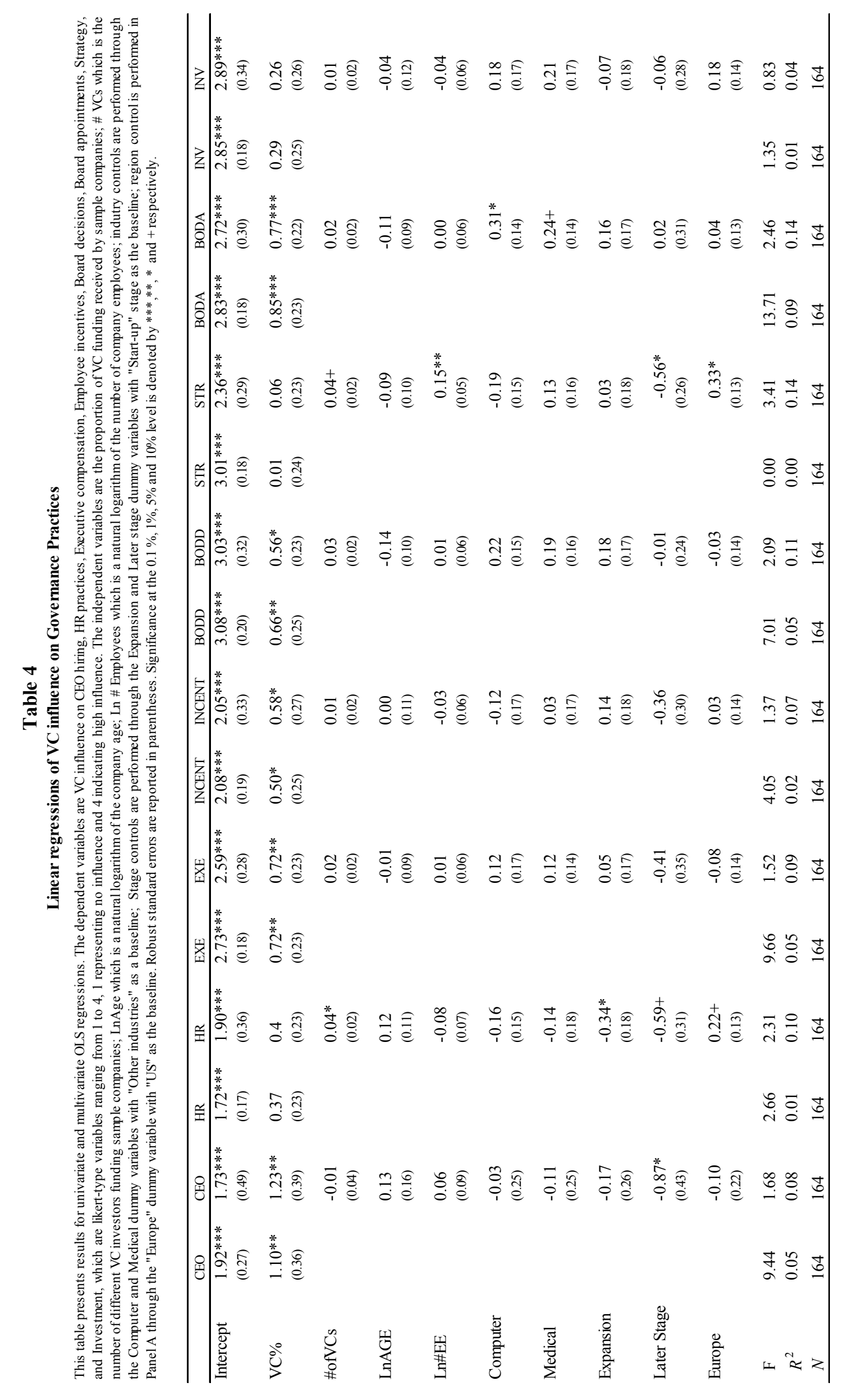


Table 5

\section{CEO replacement logistic regression}

This table presents results for a set of logistic regressions capturing the propensity of a $\mathrm{CEO}$ to be replaced after the company receives $\mathrm{VC}$ funding. The independent variables are the proportion of VC funding received by sample companies; \# VCs which is the number of different VC investors funding sample companies; LnAge which is a natural logarithm of the company age; Ln \# Employees which is a natural logarithm of the number of company employees; indutry controls are performed through the Computer and Medical dummy variables with "Other industries" as a baseline; Stage controls are performed through the Expansion and Later stage dummy variables with "Start-up" stage as the baseline; region control is performed through the "Europe" dummy variable with "US" as the baseline. Robust standard errors are reported in parentheses. Significance at the $1 \%, 5 \%$ and $10 \%$ level is denoted by $* * * * *$ and $*$ respectively. Robust standard errors are reported in parentheses. Significance at the $0.1 \%, 1 \%, 5 \%$ and $10 \%$ level is denoted by $* * *, * *, *$ and + respectively.

\begin{tabular}{|c|c|c|c|c|}
\hline & CEO-replaced & $\begin{array}{c}\text { CEO-replaced } \\
\text { Full sample }\end{array}$ & $\begin{array}{c}\text { CEO-replaced US } \\
\text { subsample }\end{array}$ & $\begin{array}{c}\text { CEO-replaced EU } \\
\text { subsample }\end{array}$ \\
\hline $\mathrm{VC} \%$ & $\begin{array}{l}1.19+ \\
(0.68)\end{array}$ & $\begin{array}{l}1.76^{*} \\
(0.81)\end{array}$ & $\begin{array}{l}2.39+ \\
(1.29)\end{array}$ & $\begin{array}{l}1.36 \\
(1.15)\end{array}$ \\
\hline \#ofVCs & & $\begin{array}{l}0.02 \\
(0.06)\end{array}$ & $\begin{array}{l}-0.04 \\
(0.08)\end{array}$ & $\begin{array}{l}0.03 \\
(0.10)\end{array}$ \\
\hline LnAGE & & $\begin{array}{l}0.97 * * \\
(0.32)\end{array}$ & $\begin{array}{l}0.69 \\
(0.53)\end{array}$ & $\begin{array}{l}1.08^{*} \\
(0.48)\end{array}$ \\
\hline Ln\#EE & & $\begin{array}{l}0.02 \\
(0.18)\end{array}$ & $\begin{array}{l}0.27 \\
(0.28)\end{array}$ & $\begin{array}{l}-0.06 \\
(0.25)\end{array}$ \\
\hline Computer & & $\begin{array}{l}0.06 \\
(0.43)\end{array}$ & $\begin{array}{l}-0.14 \\
(0.66)\end{array}$ & $\begin{array}{l}0.5 \\
(0.63)\end{array}$ \\
\hline Medical & & $\begin{array}{l}0.37 \\
(0.43)\end{array}$ & $\begin{array}{l}1.86^{* *} \\
(0.70)\end{array}$ & $\begin{array}{l}-0.74 \\
(0.72)\end{array}$ \\
\hline Expansion & & $\begin{array}{l}-0.13 \\
(0.44)\end{array}$ & $\begin{array}{l}-0.53 \\
(0.64)\end{array}$ & $\begin{array}{l}-0.15 \\
(0.70)\end{array}$ \\
\hline Later Stage & & $\begin{array}{l}-0.84 \\
(0.74)\end{array}$ & $\begin{array}{l}0.11 \\
(1.23)\end{array}$ & \\
\hline Europe & & $\begin{array}{l}-0.34 \\
(0.36)\end{array}$ & & \\
\hline$\chi^{2}$ & 3.04 & 13.74 & 16.77 & 12.55 \\
\hline Pseudo-R ${ }^{2}$ & 0.02 & 0.08 & 0.17 & 0.10 \\
\hline$N$ & 164 & 164 & 82 & 75 \\
\hline
\end{tabular}


Table 6

Ordinal Logistic Regressions of VC influence on Governance Practices

This table presents results for a set of Ordinal logistic regressions. The dependent variables are Likert-type variables ranging from 1 (no influence) to 4 (high influence) capturing the VC influence on: CEO hiring, HR practices, Executive compensation, Employee incentives, Board decisions, Board appointments, Strategy, and Investment. Parameters estimated are presented at the mean values of the independent variables. The independent variables are the proportion of VC funding received by sample companies; \# VCs which is the number of different VC investors funding sample companies; LnAge which is a natural logarithm of the company age; Ln \# Employees which is a natural logarithm of the number of company employees; indutry controls are performed through the Computer and Medical dummy variables with "Other industries" as a baseline; Stage controls are performed through the Expansion and Later stage dummy variables with "Start-up" stage as the baseline; region control is performed in Panel A through the "Europe" dummy variable with "US" as the baseline. Cut points are reported for the No influence (response 1), Low influence (response 2) and Moderate influence (Response 3) categories of the dependent variable. Robust standard errors are reported in parentheses. Significance at the $0.1 \%, 1 \%, 5 \%$ and $10 \%$ level is denoted by $* * *, * *, *$ and + respectively.

\begin{tabular}{|c|c|c|c|c|c|c|c|c|}
\hline \multicolumn{9}{|c|}{ PANEL A - FULL SAMPLE } \\
\hline & CEO & HR & EXE & INCENT & BODD & STR & BODA & INV \\
\hline \multirow[t]{2}{*}{$\overline{\mathrm{VC} \%}$} & $1.76^{* *}$ & $1.07+$ & $1.82 * *$ & $1.23^{*}$ & $1.63^{* *}$ & 0.08 & $2.05 * * *$ & 0.67 \\
\hline & $(0.61)$ & $(0.59)$ & $(0.56)$ & $(0.60)$ & $(0.61)$ & $(0.61)$ & $(0.59)$ & $(0.55)$ \\
\hline \multirow[t]{2}{*}{ \#ofVCs } & -0.01 & $0.11 *$ & 0.07 & 0.01 & 0.11 & $0.10 *$ & 0.04 & 0.02 \\
\hline & $(0.06)$ & $(0.05)$ & $(0.06)$ & $(0.06)$ & $(0.06)$ & $(0.05)$ & $(0.06)$ & $(0.06)$ \\
\hline \multirow[t]{2}{*}{ LnAGE } & 0.24 & 0.26 & 0.12 & -0.01 & -0.35 & -0.33 & -0.29 & -0.11 \\
\hline & $(0.23)$ & $(0.27)$ & $(0.22)$ & $(0.24)$ & $(0.32)$ & $(0.26)$ & $(0.26)$ & $(0.26)$ \\
\hline \multirow[t]{2}{*}{$\mathrm{Ln} \# \mathrm{EE}$} & 0.05 & -0.27 & -0.04 & -0.05 & 0.02 & $0.37 *$ & -0.06 & -0.1 \\
\hline & $(0.12)$ & $(0.16)$ & $(0.13)$ & $(0.12)$ & $(0.16)$ & $(0.15)$ & $(0.15)$ & $(0.14)$ \\
\hline \multirow[t]{2}{*}{ Computer } & 0.07 & -0.29 & 0.47 & -0.19 & 0.72 & -0.51 & $0.93^{*}$ & 0.4 \\
\hline & $(0.37)$ & $(0.35)$ & $(0.40)$ & $(0.37)$ & $(0.47)$ & $(0.38)$ & $(0.41)$ & $(0.37)$ \\
\hline \multirow[t]{2}{*}{ Medical } & -0.1 & -0.42 & 0.24 & 0.13 & 0.58 & 0.3 & 0.55 & 0.39 \\
\hline & $(0.36)$ & $(0.42)$ & $(0.35)$ & $(0.38)$ & $(0.46)$ & $(0.39)$ & $(0.40)$ & $(0.39)$ \\
\hline \multirow[t]{2}{*}{ Expansion } & -0.22 & $-0.71+$ & 0.15 & 0.42 & 0.59 & -0.03 & 0.53 & -0.07 \\
\hline & $(0.42)$ & $(0.43)$ & $(0.38)$ & $(0.39)$ & $(0.50)$ & $(0.44)$ & $(0.46)$ & $(0.39)$ \\
\hline \multirow[t]{2}{*}{ Later Stage } & $-1.25+$ & $-1.38+$ & -0.68 & -0.61 & -0.33 & $-1.46^{*}$ & 0.28 & -0.09 \\
\hline & $(0.69)$ & $(0.80)$ & $(0.86)$ & $(0.68)$ & $(0.67)$ & $(0.63)$ & $(0.78)$ & $(0.59)$ \\
\hline \multirow[t]{2}{*}{ Europe } & -0.2 & 0.46 & -0.12 & 0.09 & -0.2 & $0.84^{*}$ & 0.11 & 0.34 \\
\hline & $(0.33)$ & $(0.31)$ & $(0.33)$ & $(0.30)$ & $(0.39)$ & $(0.33)$ & $(0.35)$ & $(0.30)$ \\
\hline No Influence & 0.48 & -0.77 & -1.31 & -0.86 & -2.19 & -2.14 & -2.32 & -2.46 \\
\hline Low Influence & 1.05 & 1.38 & -0.11 & 0.98 & -0.64 & 0.13 & -0.38 & -0.86 \\
\hline Moderate Influence & 1.71 & 3.25 & 2.01 & 3.16 & 0.72 & 2.29 & 1.44 & 1.00 \\
\hline$\chi^{2}$ & 12.82 & 20.95 & 12.76 & 10.52 & 22.54 & 26.17 & 19.43 & 7.73 \\
\hline Pseudo- $R^{2}$ & 0.03 & 0.05 & 0.04 & 0.03 & 0.07 & 0.06 & 0.07 & 0.02 \\
\hline$N$ & 164 & 164 & 164 & 164 & 164 & 164 & 164 & 164 \\
\hline
\end{tabular}




\begin{tabular}{lllllllll}
\hline \multicolumn{7}{c}{ PANEL B - EUROPEAN SUB-SAMPLE } \\
\hline VC\% & CEO & HR & EXE & INCENT & BODD & STR & BODA & INV \\
& $1.65+$ & 0.68 & 0.96 & 0.76 & 0.18 & 0.47 & 1.02 & $1.55^{*}$ \\
\#ofVCs & $(0.97)$ & $(0.98)$ & $(0.85)$ & $(0.90)$ & $(0.79)$ & $(0.95)$ & $(0.85)$ & $(0.79)$ \\
& -0.16 & 0.04 & -0.15 & 0.04 & 0.02 & -0.03 & -0.17 & -0.02 \\
LnAGE & $(0.13)$ & $(0.09)$ & $(0.10)$ & $(0.07)$ & $(0.10)$ & $(0.10)$ & $(0.13)$ & $(0.12)$ \\
& $0.67^{*}$ & 0.52 & -0.03 & 0.21 & -0.51 & -0.64 & -0.27 & -0.35 \\
& $(0.34)$ & $(0.46)$ & $(0.35)$ & $(0.37)$ & $(0.38)$ & $(0.38)$ & $(0.34)$ & $(0.35)$ \\
Ln\#EE & -0.08 & -0.28 & -0.02 & -0.07 & -0.14 & 0.31 & -0.19 & -0.08 \\
& $(0.14)$ & $(0.22)$ & $(0.17)$ & $(0.15)$ & $(0.18)$ & $(0.21)$ & $(0.19)$ & $(0.18)$ \\
Computer & 0.07 & -0.69 & $1.16 *$ & 0.48 & $1.34 *$ & -0.26 & $1.23 *$ & 0.61 \\
& $(0.52)$ & $(0.49)$ & $(0.58)$ & $(0.54)$ & $(0.62)$ & $(0.51)$ & $(0.56)$ & $(0.52)$ \\
Medical & -0.1 & -0.89 & 0.61 & 0.13 & $1.86^{*}$ & 0.62 & $1.85^{*}$ & $1.08+$ \\
& $(0.55)$ & $(0.73)$ & $(0.55)$ & $(0.57)$ & $(0.82)$ & $(0.62)$ & $(0.73)$ & $(0.61)$ \\
Expansion & -0.53 & $-1.31^{*}$ & 0.67 & 0.02 & 1.37 & 0.37 & 1.12 & 0.75 \\
& $(0.64)$ & $(0.64)$ & $(0.70)$ & $(0.66)$ & $(0.92)$ & $(0.82)$ & $(0.85)$ & $(0.69)$ \\
Later Stage & $-2.98^{* * *}$ & $-3.58^{*}$ & $-2.60^{*}$ & $-1.95+$ & -0.14 & -1.58 & -0.68 & 0.97 \\
& $(0.90)$ & $(1.48)$ & $(1.16)$ & $(1.17)$ & $(0.93)$ & $(0.97)$ & $(1.25)$ & $(0.86)$ \\
No Influence & -0.25 & -2.01 & -2.11 & -1.01 & -3.82 & -4.35 & -3.88 & -2.09 \\
Low Influence & 0.59 & 0.16 & -0.92 & 0.64 & -1.76 & -0.96 & -1.49 & -0.24 \\
Moderate & 1.53 & 1.64 & 1.14 & 3.24 & -0.22 & 0.91 & 0.12 & 1.72 \\
$\chi^{2}$ & & & & & & & & \\
Pseudo- $R^{2}$ & 0.08 & 0.10 & 0.11 & 0.04 & 0.11 & 0.07 & 0.12 & 0.06 \\
$N$ & 82 & 82 & 82 & 82 & 82 & 82 & 82 & 82 \\
\hline
\end{tabular}




\begin{tabular}{lllllllll}
\hline \multicolumn{7}{l}{ PANEL C - US SUB-SAMPLE } \\
\hline VC\% & CEO & HR & EXE & INCENT & BODD & STR & BODA & INV \\
& $1.61+$ & 1.2 & $3.14^{* *}$ & $1.72^{*}$ & $2.95^{* *}$ & -0.31 & $2.86^{* *}$ & -0.19 \\
\#ofVCs & $(0.92)$ & $(0.78)$ & $(0.98)$ & $(0.76)$ & $(1.09)$ & $(0.86)$ & $(1.00)$ & $(0.87)$ \\
& 0.01 & 0.12 & 0.14 & -0.04 & 0.12 & $0.14^{*}$ & 0.1 & 0.05 \\
LnAGE & $(0.08)$ & $(0.06)$ & $(0.09)$ & $(0.08)$ & $(0.08)$ & $(0.06)$ & $(0.09)$ & $(0.06)$ \\
& -0.17 & -0.04 & 0.18 & -0.32 & 0.01 & 0.03 & -0.1 & 0.16 \\
& $(0.34)$ & $(0.36)$ & $(0.37)$ & $(0.38)$ & $(0.59)$ & $(0.42)$ & $(0.47)$ & $(0.44)$ \\
Ln\#EE & 0.26 & -0.26 & -0.11 & 0.02 & 0.25 & $0.58^{*}$ & 0.11 & -0.16 \\
& $(0.31)$ & $(0.26)$ & $(0.24)$ & $(0.22)$ & $(0.32)$ & $(0.26)$ & $(0.27)$ & $(0.29)$ \\
Computer & 0.04 & 0.19 & -0.01 & -0.79 & 0.07 & -0.58 & 0.91 & 0.28 \\
& $(0.61)$ & $(0.53)$ & $(0.65)$ & $(0.59)$ & $(0.81)$ & $(0.66)$ & $(0.64)$ & $(0.60)$ \\
Medical & 0.34 & 0.46 & 0.8 & 0.37 & -0.01 & 0.17 & 0.18 & -0.38 \\
& $(0.55)$ & $(0.60)$ & $(0.53)$ & $(0.60)$ & $(0.74)$ & $(0.67)$ & $(0.57)$ & $(0.55)$ \\
Expansion & -0.03 & -0.41 & -0.1 & 0.61 & 0.39 & -0.29 & 0.49 & -0.58 \\
& $(0.55)$ & $(0.57)$ & $(0.54)$ & $(0.52)$ & $(0.70)$ & $(0.63)$ & $(0.60)$ & $(0.54)$ \\
Later Stage & -0.52 & -0.04 & 0.22 & 0.13 & -1.45 & $-1.91^{*}$ & 0.32 & -0.85 \\
& $(1.07)$ & $(1.01)$ & $(0.95)$ & $(0.93)$ & $(0.95)$ & $(0.93)$ & $(0.99)$ & $(0.79)$ \\
No Influence & 1.12 & -0.43 & -1.37 & -1.05 & -0.14 & -1.08 & -0.97 & -3.34 \\
Low Influence & 1.52 & 1.82 & 0.47 & 1.12 & 0.97 & 0.83 & 0.69 & -1.84 \\
Moderate & 2.01 & 4.91 & 3.26 & 2.99 & 2.30 & 3.47 & 3.11 & 0.07 \\
$\chi^{2}$ & & & & & & & & \\
$P$ Pseudo- $R^{2}$ & 0.04 & 0.05 & 0.13 & 0.05 & 0.12 & 0.08 & 0.13 & 0.02 \\
$N$ & 82 & 82 & 82 & 82 & 82 & 82 & 82 & 82 \\
\hline
\end{tabular}




\section{Table A1}

Questionnaire

This table reproduces the questionnaire administered to CEOs and CFOs of a sample of 500 randomly selected VC-backed companies in Europe and the US. The form has been sent by email and fax, and followed up by two rounds of reminder messages. Response rate has been $32.8 \%$ or 164 companies.

Disclaimer

Data provided here will be used to derive series of aggregate analysis. Please rest assured that your answers will be kept strictly CONFIDENTIAL and will not be disclosed individually to the public.

Company information

1 Firm Name

2 Year Founded (YYYY-MM-DD)

3 Where your head office is geographically located?

4 Industry classification of the Firm (select where most appropriate)

Agriculture/Fisheries Manufacturing-light

Computer related Media

Conglomerates Medical

Construction Mining and metals

Consumer products/services Retail/Wholesale

Electronics Services Non-financial

Ecology Telecommunications

Financial services Textiles and clothing

Infrastructure Transportation/Distribution

Information technology Travel/Hospitality

Leisure/Entertainment Utilities

Manufacturing-Heavy Other

5 Approximately how many employees working in your firm?

6 What is your firm's current stage of operation?

Start-up/Early Stage

Expansion/Development

Later Stage

7 Approximately what is the percentage amount of venture capital tinancing of total tinancing that your firm used? (e.g. $20 \%$ of total financing)

8 Where is your firm's source of Venture Capital funding geographically located?

VC Influence Section

9 Has your firm hired an outside Chief Executive Officer (CEO) after receiving Venture Capital funding? (Yes/No)

For questions 10-17, please use the following rating scale: $1=$ No influence to $4=$ High influence

10 To what extent Venture Capital firms (VCs) are influential in your firm's CEO hiring decisions?

11 To what extent VCs are influential in your firm's overall 'Human Resource Practices” (e.g. training, career development, employment security)?

12 To what extent VCs are influential in your firm's decisions on the level of Executive Compensation?

13 To what extent VCs are influential in determining your employees' incentives?

14 To what extent VCs are influential in your firm's board of directors' decisions such as Takeover?

15 To what extent VCs are influential in your firm's strategic direction?

16 To what extent VCs are influential in your firm's board appointments?

17 To what extent VCs are influential in your firm's investment decisions?

\section{Control questions}

18 Please state any other function of VCs that affects directly or indirectly any business in your firm.

19 Please state your position in the firm. 


\section{Figure 1}

\section{Full sample predicted probabilities}

This figure plots predicted probabilities for the four dependent variables significant at the $1 \%$ level or more from the full. sample ordinal logistic regression reported in Table 6, Panel A. The four variables are : influence on CEO hiring (CEO), influence on Executive compensation (EXE), influence on Board of directors decisions (BODD) and influence on Board of directrors appointment (BODA). The dashed lines plot the predicted probabilities for the 'No or low influence' outcome (i.e. response category=1), while the solid lines report the predicted probabilities associated with the 'High influence' outcome (i.e. response category=4). Predicted probabilities are computed setting all other variables at their mean values. The vertical line reports the mean level of VC contribution.

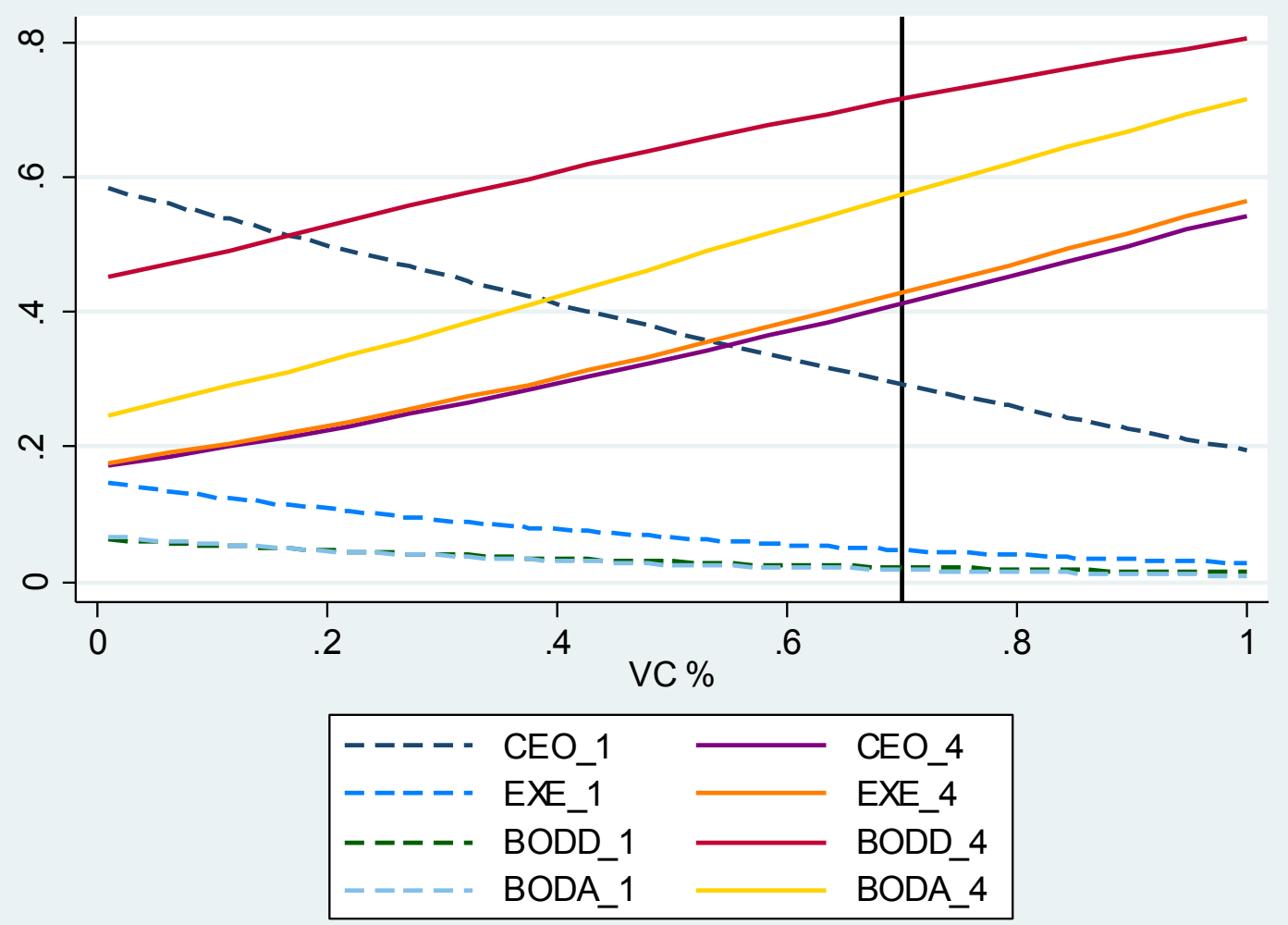




\section{Figure 2}

\section{US sub-sample predicted probabilities}

This figure plots predicted probabilities for the three dependent variables significant at the $1 \%$ level or more from the US sub-sample ordinal logistic regression reported in Table 6 Panel C. The three variables are: influence on Executive compensation (EXE), influence on Board of directors decisions (BODD) and influence on Board of directrors appointment (BODA). The dashed lines plot the predicted probabilities for the 'No or low influence' outcome (i.e. response category=1), while the solid lines report the predicted probabilities associated with the 'High influence' outcome (i.e. response category=4). Predicted probabilities are computed setting all other variables at their mean values. The vertical line reports the mean level of VC contribution.

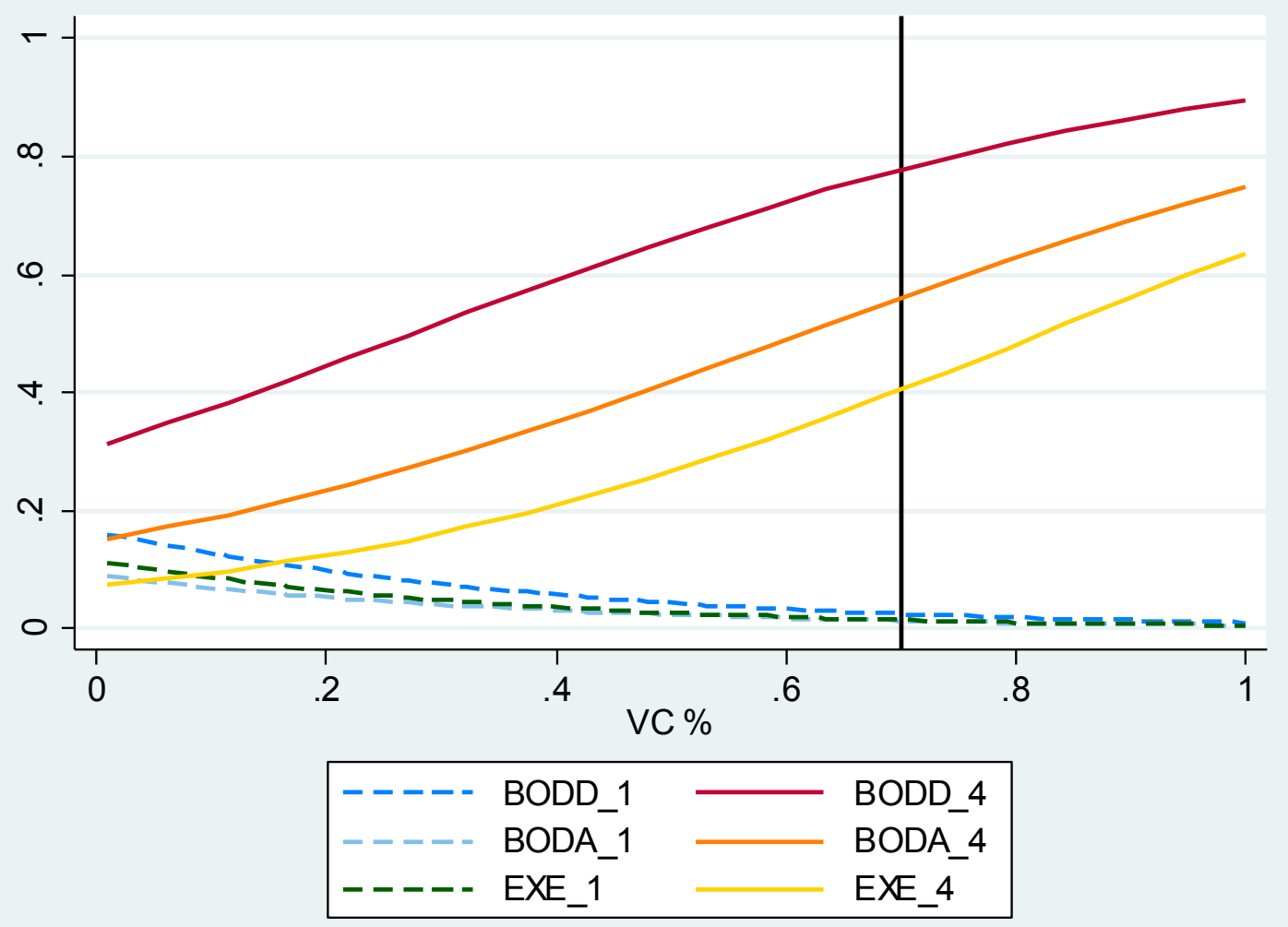


Figure 3

\section{EU-US subsample comparison}

This figure plots predicted probabilities for the three most significant dependent variables from the US and European sub-samples ordinal logistic regression reported in Table 6, Panels B and C. The three variables are : influence on Executive compensation (EXE) and influence on Board of directors decisions (BODD) from the US sub-sample and influence on Investment decisions from the EU subsample. We report predicted probabilities for the 'High influence' outcome (i.e. response category=4). The dashed lines plot the predicted probabilities for the European predicted probabilities, while the solid lines report the predicted probabilities associated with the US data. Predicted probabilities are computed setting all other variables at their mean values. The vertical line reports the mean level of VC contribution.

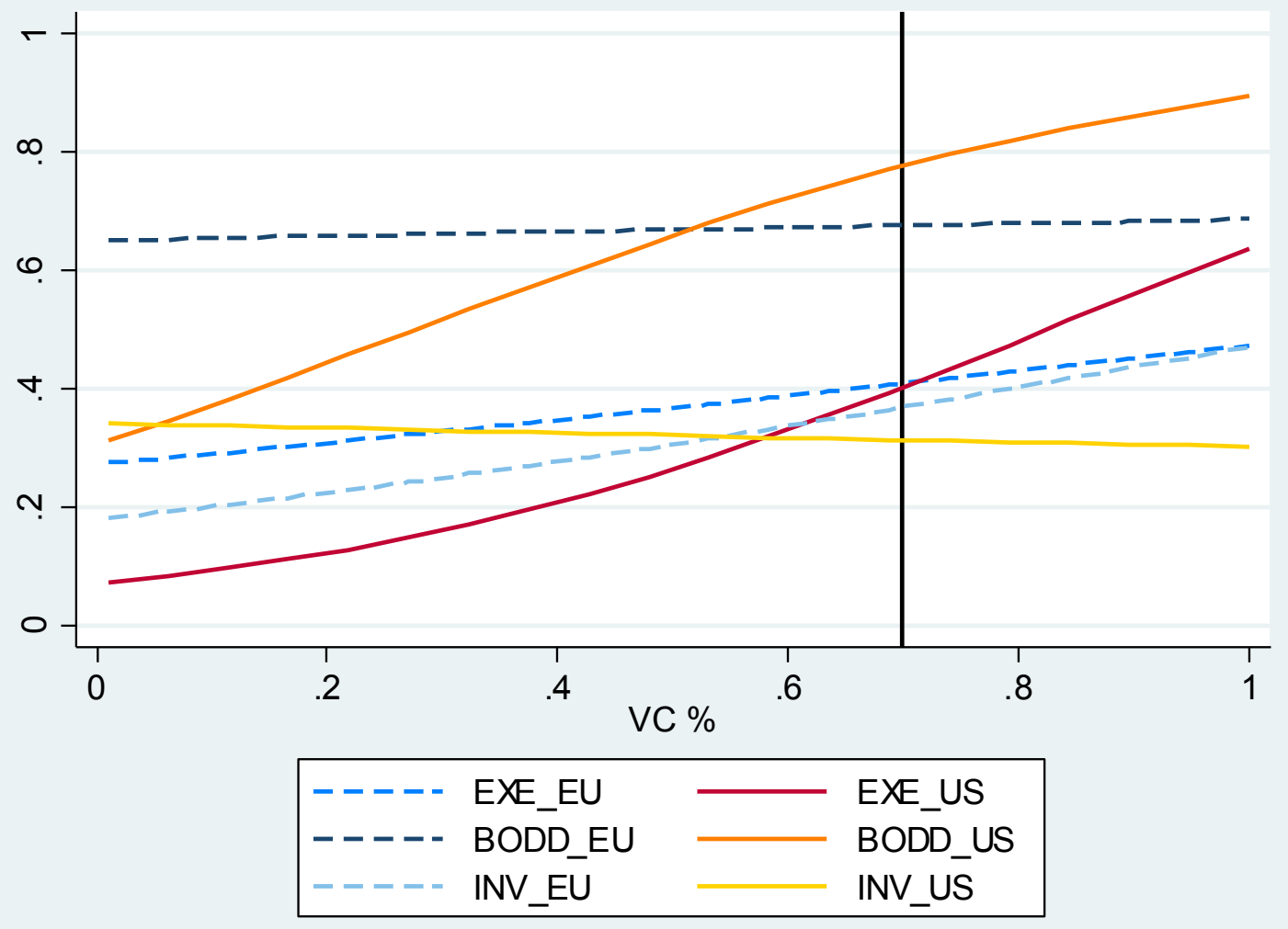




\section{Table A1 \\ Legal origin control}

This table reports summary statistic of the US and European subsample and additional statistics for the three european legal systems plus UK.

Background characteristics

\begin{tabular}{|c|c|c|c|c|c|c|}
\hline & US & $\mathrm{EU}$ & UK & German & French & Scandinavian \\
\hline Mean firm age (years) & 5.439 & 6.805 & 7.083 & 7.063 & 7.8 & 5.82 \\
\hline Mean number of VCs/Firm & 4.415 & 3.061 & 3.333 & 3.3 & 3.267 & 2.593 \\
\hline Mean VC funding/firm & $72.21 \%$ & $68.61 \%$ & $73.66 \%$ & $71.62 \%$ & $65.55 \%$ & $68.00 \%$ \\
\hline \multicolumn{7}{|c|}{ Stage Distribution by Region and Legal system } \\
\hline StartUp & 0.293 & 0.195 & 0.225 & 0.25 & 0.067 & 0.185 \\
\hline Expansion & 0.573 & 0.720 & 0.708 & 0.625 & 0.8 & 0.741 \\
\hline Later & 0.134 & 0.085 & 0.067 & 0.125 & 0.133 & 0.074 \\
\hline \multicolumn{7}{|c|}{ Industry Distribution by Region and Legal system } \\
\hline Computer & 0.329 & 0.244 & 0.291 & 0.125 & 0.267 & 0.259 \\
\hline Medical & 0.268 & 0.207 & 0.25 & 0.313 & 0.066 & 0.185 \\
\hline Other & 0.403 & 0.549 & 0.459 & 0.562 & 0.667 & 0.556 \\
\hline
\end{tabular}




\section{Table A2}

\section{Linear Regressions of VC Influence on Multi-Item Governance Variables}

This table presents results for univariate and multivariate OLS regressions estimated with multi-item dependent variables. The dependent variables are Likert-type variables ranging from 1 (no influence) to 4 (high influence) capturing the VC influence on a comprehensive governance variable (GOV), on the Strategic direction of the venture (STRAT) and the broad area of Human Resource Practices (HRP). The independent variables are the proportion of VC funding received by sample companies; \# VCs which is the number of different VC investors funding sample companies; LnAge which is a natural logarithm of the company age; Ln \# Employees which is a natural logarithm of the number of company employees; indutry controls are performed through the Computer and Medical dummy variables with "Other industries" as a baseline; Stage controls are performed through the Expansion and Later stage dummy variables with "Start-up" stage as the baseline; region control is performed through the "Europe" dummy variable with "US" as the baseline. Robust standard errors are reported in parentheses. Significance at the $0.1 \%, 1 \%, 5 \%$ and $10 \%$ level is denoted by $* * * * *, *$ and + respectively.

\begin{tabular}{|c|c|c|c|c|c|c|}
\hline & GOV & GOV & STRAT & STRAT & HRP & HRP \\
\hline Intercept & $\begin{array}{c}2.696^{* * * *} \\
(0.123)\end{array}$ & $\begin{array}{c}2.622 * * * \\
(0.225)\end{array}$ & $\begin{array}{c}3.052 * * * \\
(0.171)\end{array}$ & $\begin{array}{c}2.840 * * * \\
(0.281)\end{array}$ & $\begin{array}{c}2.303 * * * \\
(0.158)\end{array}$ & $\begin{array}{c}2.213 * * * \\
(0.297)\end{array}$ \\
\hline $\mathrm{VC} \%$ & $\begin{array}{c}0.388^{*} \\
(0.168)\end{array}$ & $\begin{array}{c}0.449 * * \\
(0.170)\end{array}$ & $\begin{array}{c}0.515^{*} \\
(0.221)\end{array}$ & $\begin{array}{c}0.460^{*} \\
(0.206)\end{array}$ & $\begin{array}{c}0.584 * * \\
(0.209)\end{array}$ & $\begin{array}{c}0.661 * * \\
(0.218)\end{array}$ \\
\hline \#ofVCs & & $\begin{array}{l}0.001 \\
(0.016)\end{array}$ & & $\begin{array}{l}0.026 \\
(0.020)\end{array}$ & & $\begin{array}{c}0.02 \\
(0.020)\end{array}$ \\
\hline LnAGE & & $\begin{array}{c}0.02 \\
(0.078)\end{array}$ & & $\begin{array}{c}-0.1 \\
(0.097)\end{array}$ & & $\begin{array}{l}0.032 \\
(0.088)\end{array}$ \\
\hline Ln\#EE & & $\begin{array}{c}-0.019 \\
(0.038)\end{array}$ & & $\begin{array}{l}0.015 \\
(0.057)\end{array}$ & & $\begin{array}{l}0.011 \\
(0.056)\end{array}$ \\
\hline Computer & & $\begin{array}{l}0.003 \\
(0.126)\end{array}$ & & $\begin{array}{l}0.194 \\
(0.139)\end{array}$ & & $\begin{array}{c}-0.136 \\
(0.156)\end{array}$ \\
\hline Medical & & $\begin{array}{l}0.099 \\
(0.122)\end{array}$ & & $\begin{array}{l}0.205 \\
(0.140)\end{array}$ & & $\begin{array}{l}0.017 \\
(0.143)\end{array}$ \\
\hline Expansion & & $\begin{array}{l}0.051 \\
(0.150)\end{array}$ & & $\begin{array}{l}0.156 \\
(0.165)\end{array}$ & & $\begin{array}{c}-0.047 \\
(0.156)\end{array}$ \\
\hline Later Stage & & $\begin{array}{l}-0.241 \\
(0.202)\end{array}$ & & $\begin{array}{c}-0.062 \\
(0.269)\end{array}$ & & $\begin{array}{c}-0.672 * \\
(0.260)\end{array}$ \\
\hline Europe & & $\begin{array}{l}0.062 \\
(0.108)\end{array}$ & & $\begin{array}{l}0.122 \\
(0.126)\end{array}$ & & $\begin{array}{c}0.02 \\
(0.125)\end{array}$ \\
\hline $\mathrm{F}$ & 5.37 & 1.51 & 5.43 & 1.62 & 7.83 & 2.65 \\
\hline$R^{2}$ & 0.03 & 0.06 & 0.04 & 0.09 & 0.04 & 0.11 \\
\hline$N$ & 164 & 164 & 164 & 164 & 164 & 164 \\
\hline
\end{tabular}




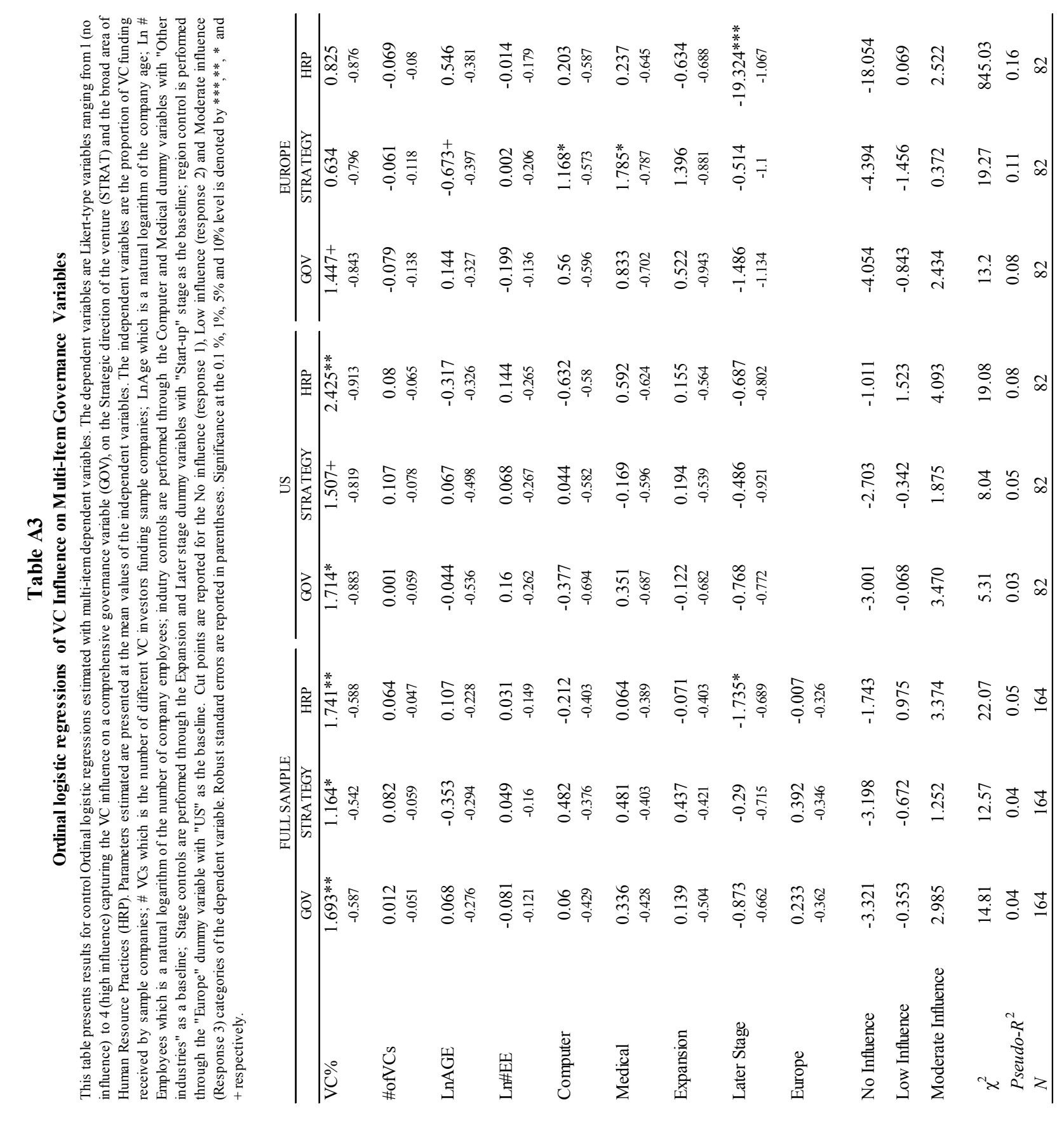




\section{Table A4}

\section{US-UK Ordinal logistic control regressions}

This table reports ordinal regression coefficients for a set of control regressions run on the US subsample and a sample of UK only companies to control for the possible anglosaxon country biases. The table reports results only for our two main independent variables, namely the size of the VC stake and the syndication metric. Robust standard errors are reported in parentheses. Significance at the $0.1 \%, 1 \%, 5 \%$ and $10 \%$ level is denoted by $* * * * *, *$ and + respectively.

\begin{tabular}{lcccccccc}
\multicolumn{10}{c}{$\mathrm{VC} \%$} \\
\hline US & CEO & HR & EXE & INCENT & BODD & STR & BODA & INV \\
& $1.610+$ & 1.203 & $3.145^{* *}$ & $1.723^{*}$ & $2.954^{* *}$ & -0.305 & $2.860^{* *}$ & -0.187 \\
& $(0.924)$ & $(0.779)$ & $(0.977)$ & $(0.758)$ & $(1.085)$ & $(0.860)$ & $(0.997)$ & $(0.868)$ \\
EU & $1.647+$ & 0.683 & 0.962 & 0.764 & 0.177 & 0.469 & 1.019 & $1.545^{*}$ \\
& $(0.973)$ & $(0.978)$ & $(0.847)$ & $(0.898)$ & $(0.787)$ & $(0.949)$ & $(0.846)$ & $(0.785)$ \\
& & & & & & & & \\
UK & 3.938 & 2.002 & 3.938 & $4.431^{*}$ & 4.023 & $5.140^{*}$ & 3.815 & $1.369+$ \\
& $(2.704)$ & $(2.384)$ & $(2.704)$ & $(2.246)$ & $(3.082)$ & $(2.447)$ & $(2.853)$ & $(1.313)$ \\
\hline & & & & & & & & \\
& & & & & & & & \\
\hline & CEO & HR & EXE & INCENT & BODD & STR & BODA & INV \\
\hline US & 0.011 & $0.116+$ & 0.135 & -0.040 & 0.121 & $0.141^{*}$ & 0.104 & 0.045 \\
& $(0.081)$ & $(0.061)$ & $(0.088)$ & $(0.083)$ & $(0.083)$ & $(0.064)$ & $(0.089)$ & $(0.063)$ \\
& & & & & & & & \\
EU & -0.164 & 0.039 & -0.153 & 0.042 & 0.023 & -0.029 & -0.172 & -0.024 \\
& $(0.127)$ & $(0.087)$ & $(0.103)$ & $(0.073)$ & $(0.101)$ & $(0.097)$ & $(0.127)$ & $(0.118)$ \\
& & & & & & & & \\
UK & $-0.462 * *$ & 0.095 & $-0.323^{*}$ & -0.001 & $-0.607 *$ & $-0.437^{*}$ & $-0.548 * * *$ & -0.259 \\
& $(0.161)$ & $(2.384)$ & $(0.140)$ & $(0.144)$ & 0.290 & $(0.185)$ & $(0.155)$ & $(0.201)$ \\
\hline
\end{tabular}




\section{Table A5}

\section{Ordinal logistic regressions with Hofstede Indices}

This table presents results for a set of Ordinal logistic regressions. The dependent variables are Likert-type variables ranging from 1 (no influence) to 4 (high influence) capturing the VC influence on: CEO hiring, HR practices, Executive compensation, Employee incentives, Board decisions, Board appointments, Strategy, and Investment. Parameters estimated are presented at the mean values of the independent variables. The independent variables are the proportion of VC funding received by sample companies; \# VCs which is the number of different VC investors funding sample companies; LnAge which is a natural logarithm of the company age; Ln \# Employees which is a natural logarithm of the number of company employees; indutry controls are performed through the Computer and Medical dummy variables with "Other industries" as a baseline; Stage controls are performed through the Expansion and Later stage dummy variables with "Start-up" stage as the baseline; Controls for cultural influence is performed through the four Hofstede indices, namely: PDI (Power Distance Index), IDV (Individualism), MAS (Masculinity), UAI (Uncertainty Avoidance Index). Cut points for different are omitted reported for the No influence (response 1), Low influence (response 2) and Moderate influence (Response 3) categories of the dependent variable. Robust standard errors are reported in parentheses. Significance at the $0.1 \%, 1 \%, 5 \%$ and $10 \%$ level is denoted by $* * *, *, *$ and + respectively.

\begin{tabular}{|c|c|c|c|c|c|c|c|c|}
\hline & $\mathrm{CEO}$ & $\mathrm{HR}$ & EXE & INCENT & BODD & STR & BODA & INV \\
\hline $\mathrm{VC} \%$ & $\begin{array}{c}1.675 * * \\
(0.648)\end{array}$ & $\begin{array}{c}1.193^{*} \\
(0.584)\end{array}$ & $\begin{array}{c}1.739 * * \\
(0.580)\end{array}$ & $\begin{array}{c}1.289 * \\
(0.589)\end{array}$ & $\begin{array}{c}1.570^{*} \\
(0.674)\end{array}$ & $\begin{array}{l}0.015 \\
(0.619)\end{array}$ & $\begin{array}{c}2.072 * * * \\
(0.627)\end{array}$ & $\begin{array}{l}0.605 \\
(0.605)\end{array}$ \\
\hline \#ofVCs & $\begin{array}{c}-0.004 \\
(0.061)\end{array}$ & $\begin{array}{c}0.123 * \\
(0.051)\end{array}$ & $\begin{array}{l}0.074 \\
(0.058)\end{array}$ & $\begin{array}{l}0.018 \\
(0.058)\end{array}$ & $\begin{array}{c}0.113+ \\
(0.060)\end{array}$ & $\begin{array}{c}0.108^{*} \\
(0.050)\end{array}$ & $\begin{array}{l}0.048 \\
(0.057)\end{array}$ & $\begin{array}{c}0.03 \\
(0.056)\end{array}$ \\
\hline LnAGE & $\begin{array}{l}0.228 \\
(0.238)\end{array}$ & $\begin{array}{l}0.244 \\
(0.256)\end{array}$ & $\begin{array}{l}0.126 \\
(0.223)\end{array}$ & $\begin{array}{r}-0.017 \\
(0.246)\end{array}$ & $\begin{array}{r}-0.352 \\
(0.313)\end{array}$ & $\begin{array}{c}-0.323 \\
(0.268)\end{array}$ & $\begin{array}{r}-0.291 \\
(0.262)\end{array}$ & $\begin{array}{c}-0.118 \\
(0.275)\end{array}$ \\
\hline Ln\#EE & $\begin{array}{l}0.083 \\
(0.137)\end{array}$ & $\begin{array}{c}-0.248 \\
(0.164)\end{array}$ & $\begin{array}{c}-0.039 \\
(0.137)\end{array}$ & $\begin{array}{c}-0.018 \\
(0.126)\end{array}$ & $\begin{array}{l}0.063 \\
(0.169)\end{array}$ & $\begin{array}{c}0.393 * \\
(0.154)\end{array}$ & $\begin{array}{c}-0.019 \\
(0.152)\end{array}$ & $\begin{array}{c}-0.086 \\
(0.147)\end{array}$ \\
\hline Computer & $\begin{array}{l}0.052 \\
(0.383)\end{array}$ & $\begin{array}{r}-0.311 \\
(0.353)\end{array}$ & $\begin{array}{c}0.56 \\
(0.424)\end{array}$ & $\begin{array}{r}-0.191 \\
(0.367)\end{array}$ & $\begin{array}{l}0.727 \\
(0.499)\end{array}$ & $\begin{array}{r}-0.515 \\
(0.390)\end{array}$ & $\begin{array}{c}0.946^{*} \\
(0.426)\end{array}$ & $\begin{array}{c}0.45 \\
(0.383)\end{array}$ \\
\hline Medical & $\begin{array}{r}-0.112 \\
(0.382)\end{array}$ & $\begin{array}{c}-0.388 \\
(0.438)\end{array}$ & $\begin{array}{l}0.194 \\
(0.357)\end{array}$ & $\begin{array}{l}0.201 \\
(0.377)\end{array}$ & $\begin{array}{l}0.579 \\
(0.537)\end{array}$ & $\begin{array}{l}0.259 \\
(0.395)\end{array}$ & $\begin{array}{l}0.599 \\
(0.416)\end{array}$ & $\begin{array}{l}0.366 \\
(0.404)\end{array}$ \\
\hline Expansion & $\begin{array}{c}-0.265 \\
(0.425)\end{array}$ & $\begin{array}{c}-0.799+ \\
(0.463)\end{array}$ & $\begin{array}{l}0.208 \\
(0.395)\end{array}$ & $\begin{array}{l}0.341 \\
(0.394)\end{array}$ & $\begin{array}{l}0.569 \\
(0.532)\end{array}$ & $\begin{array}{c}-0.035 \\
(0.445)\end{array}$ & $\begin{array}{l}0.492 \\
(0.478)\end{array}$ & $\begin{array}{c}-0.032 \\
(0.430)\end{array}$ \\
\hline Later Stage & $\begin{array}{c}-1.289+ \\
(0.715)\end{array}$ & $\begin{array}{c}-1.587+ \\
(0.892)\end{array}$ & $\begin{array}{c}-0.617 \\
(0.873)\end{array}$ & $\begin{array}{c}-0.792 \\
(0.665)\end{array}$ & $\begin{array}{c}-0.315 \\
(0.756)\end{array}$ & $\begin{array}{c}-1.531 * \\
(0.660)\end{array}$ & $\begin{array}{l}0.214 \\
(0.829)\end{array}$ & $\begin{array}{r}-0.095 \\
(0.643)\end{array}$ \\
\hline PDI & $\begin{array}{c}-0.047 \\
(0.055)\end{array}$ & $\begin{array}{c}-0.073 \\
(0.064)\end{array}$ & $\begin{array}{c}-0.089 \\
(0.073)\end{array}$ & $\begin{array}{c}-0.018 \\
(0.059)\end{array}$ & $\begin{array}{c}-0.098 \\
(0.072)\end{array}$ & $\begin{array}{l}0.025 \\
(0.071)\end{array}$ & $\begin{array}{c}-0.039 \\
(0.068)\end{array}$ & $\begin{array}{r}-0.092 \\
(0.061)\end{array}$ \\
\hline IDV & $\begin{array}{l}0.047 \\
(0.052)\end{array}$ & $\begin{array}{c}0.02 \\
(0.059)\end{array}$ & $\begin{array}{l}0.045 \\
(0.059)\end{array}$ & $\begin{array}{l}0.029 \\
(0.048)\end{array}$ & $\begin{array}{l}0.078 \\
(0.066)\end{array}$ & $\begin{array}{c}-0.078 \\
(0.062)\end{array}$ & $\begin{array}{l}0.029 \\
(0.058)\end{array}$ & $\begin{array}{l}0.016 \\
(0.055)\end{array}$ \\
\hline MAS & $\begin{array}{c}-0.023 \\
(0.021)\end{array}$ & $\begin{array}{c}-0.031 \\
(0.027)\end{array}$ & $\begin{array}{l}-0.02 \\
(0.026)\end{array}$ & $\begin{array}{c}-0.026 \\
(0.020)\end{array}$ & $\begin{array}{c}-0.047+ \\
(0.029)\end{array}$ & $\begin{array}{l}0.013 \\
(0.028)\end{array}$ & $\begin{array}{c}-0.027 \\
(0.026)\end{array}$ & $\begin{array}{c}-0.026 \\
(0.024)\end{array}$ \\
\hline UAI & $\begin{array}{l}0.028 \\
(0.048)\end{array}$ & $\begin{array}{l}0.053 \\
(0.057)\end{array}$ & $\begin{array}{l}0.048 \\
(0.058)\end{array}$ & $\begin{array}{l}0.022 \\
(0.045)\end{array}$ & $\begin{array}{c}0.06 \\
(0.062)\end{array}$ & $\begin{array}{c}-0.044 \\
(0.062)\end{array}$ & $\begin{array}{l}0.021 \\
(0.056)\end{array}$ & $\begin{array}{l}0.045 \\
(0.054)\end{array}$ \\
\hline$\chi^{2}$ & 21.62 & 26.99 & 15.29 & 17.43 & 46.85 & 31.15 & 28.02 & 25.61 \\
\hline Pseudo- $R^{2}$ & 0.04 & 0.07 & 0.05 & 0.04 & 0.11 & 0.07 & 0.09 & 0.05 \\
\hline$N$ & 164 & 164 & 164 & 164 & 164 & 164 & 164 & 164 \\
\hline
\end{tabular}


i A "portfolio company" is common jargon for a firm which received financing from one or more Venture Capital investors. Since VCs are exposed to significant default risk in their investment, they adopt a diversification strategy by investing in a relatively large number of companies, thus creating a portfolio that reduces the overall risk for the $\mathrm{VC}$.

ii The definition of "aggressive" vs "conservative" accounting practices is the one adopted by Hochberg (2004) and Teoh, Welch, and Wong (1998) who consider accounting policies as "aggressive" when characterized by higher discretionary accruals as opposed to lower discretionary accruals for conservative policies.

iii In this paper we do not aim at assessing the superiority of one specific governance system. The empirical evidence shows that US governance practices are more granular than non-US ones. This translates into higher rankings in worldwide surveys and seems to be correlated with company value. We do not claim that the US system is superior in ideal terms. On the contrary, some countries do show superior practices in some areas. For instance more separation between CEO and Chairman in the UK or mandatory employee board representation in Germany. Whether the higher ranking of the US system is due to methodological flaws or actual superiority is out of the scope of our research.

iv Jääskeläinen (2009) provides a complete review of the theoretical and empirical research on this VC behavior.

${ }^{v}$ One of the studies relying on VentureEconomics data after it has been purchased by Securities Data Company (SDC) and become accessible to researchers in 1991, is Lerner (1995). Please refer to Lerner (1995) for further description of VentureEconomics.

${ }^{\mathrm{vi}}$ In this calculation process, we exclude United States as it clearly represents an outlier in the sample of countries here considered.

vii The identical number of companies (82) in the US and European sub-sample is a random outcome of the selection process.

viii For a discussion on Likert scale modeling see Dawes (2008)

${ }^{i x}$ In our sample the geographical location of the company and that of the lead VC overlap in all but one case.

${ }^{\mathrm{x}}$ In Table A1 in the Internet Appendix we report analytical summary statistics for the US, UK and European subsamples. The results show that the UK figures are aligned to those of the other European systems and different from those observed in the US subsample, thus supporting our choice of including the UK into the European subsample.

${ }^{x i}$ In the European sub-sample regression the dummy variable for the later stage has been dropped as it predicted perfectly success. This is a common outcome when the number of observation is very small (7) as in our case)

xii Predicted probabilities are estimated at the mean values of the independent variables. Cut points for the response categories are provided at the bottom of the page.

xiii In Table A4 in the Internet Appendix we report results from running separate regressions for the UK to further control for possible biases induced by a greater similarity of the UK system with the US one. Results do not support this view.

${ }^{\text {xiv }}$ All our results are robust to several controls and in particular to re-grouping by legal system, replacing nominative industry classification with industry market-to-book ratios, introducing Hofstede cultural indices. We are particularly grateful to an anonymous reviewer for suggesting these controls. We refer the interested reader to the Internet Appendix, Tables A4 and A5 for additional details. 